
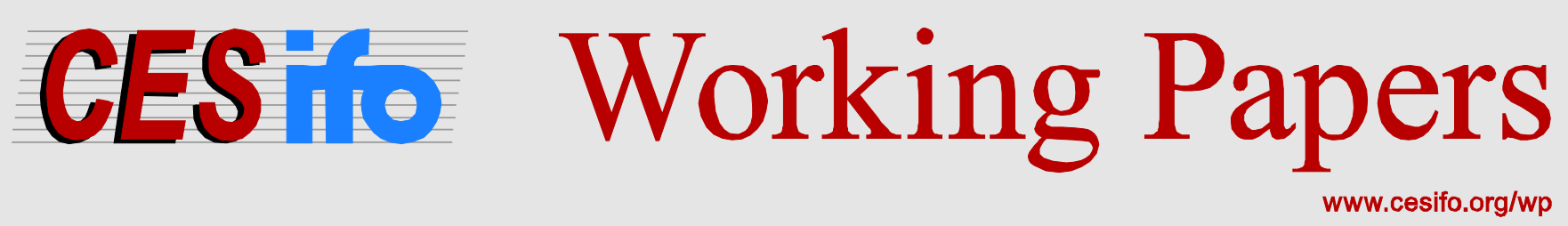

\title{
Explaining the Size Differences of Exporter Productivity Premia: Theory and Evidence
}

\author{
Ingo Geishecker \\ Philipp J.H. Schröder \\ Allan Sørensen
}

CESIFO WORKING PAPER No. 4630

CATEgory 8: Trade Policy

FEBRUARY 2014

An electronic version of the paper may be downloaded
• from the SSRN website:
• from the RePEc website:
- from the CESifo website: 


\title{
Explaining the Size Differences of Exporter Productivity Premia: Theory and Evidence
}

\begin{abstract}
Why is it that exporter productivity premia (EPP) differ so widely in size? We take this question to the theory and to the data. We derive the sectoral EPP in a standard heterogeneous firms trade model and apply the insights from the model to 13 years of data for all Danish manufacturing firms. We show that a significant share of the observed variation in EPPs across sectors, and hence across countries, can be explained by the variation in productivity dispersion, trade costs and the elasticity of substitution.
\end{abstract}

JEL-Code: F120, F140, D240, O470.

Keywords: intra-industry trade, exporter productivity, firm-level data, heterogeneous firms.

\author{
Ingo Geishecker \\ European University Viadrina \\ Faculty of Business Administration \\ and Economics \\ Germany - Frankfurt (Oder) \\ geishecker@europa-uni.de
}

\author{
Philipp J.H. Schröder \\ Aarhus University \\ School of Business and Social Sciences \\ Department of Economics and Business \\ Denmark - 8210 Aarhus V \\ psc@asb.dk
}

\author{
Allan Sørensen \\ Aarhus University \\ School of Business and Social Sciences \\ Department of Economics and Business \\ Denmark-8210 Aarhus V \\ allans@asb.dk
}

January 2014

The paper benefited from the comments from Andrew Bernard, Gabriel Felbermayr, Benjamin Jung, Giammario Impullitti and participants at the ETSG conference 2012, the Munich International Economics Seminar 2012, seminar at Johannes Gutenberg-University Mainz 2012, the Royal Economic Society conference 2013, the Göttinger Workshop "Internationale Wirtschaftsbeziehungen" 2013, the CESifo - Delphi Conference on The Economics of Firm Exporting 2013 and the Danish International Economics Workshop 2013. The authors acknowledge financial support from the Tuborg Foundation. 


\section{Introduction}

The existence of persistent productivity dispersion is a vivid research topic in a number of fields ranging from macroeconomics to industrial organization (Syverson, 2011). Maybe the most prominent aggregate manifestation of such productivity dispersions stems from the field of international economics, namely the stylized fact of a positive exporter productivity premia (EPP). Combined with elegant new theories (e.g. Melitz, 2003) exporter productivity premia have intrigued empirical and theoretical researchers in international economics for the past decades; see Greenaway and Kneller (2007), Wagner (2007, 2012), Redding (2011) and Bernard et al. (2012) for surveys. Despite the impressive volume of analyses, the central question as to the underlying drivers of the EPP magnitude remains open. ${ }^{1}$ What determines the size of the EPP and why is it that exporter productivity premia vary so widely in size across countries and across industries? Empirically, exporter productivity premia range, for example in Europe, from 7 (0)\% in Sweden to 58 (10)\% in Belgium for identical pooled (fixed effects) estimation specifications on comparable data (ISGEP, 2008, Table 4). On the sectoral level - the focus of the present paper - the issue is even more pronounced. For Denmark total factor productivity (TFP) based fixed effects EPP estimates across 99 manufacturing sectors span from $4 \%$ to $71 \%$. On first sight, theory is silent on such size differences and empirical research has produced such results largely uncommented.

To be fair, short of classifying EPP differences in magnitude simply as idiosyncratic characteristics of sectors or differences in econometric estimation strategies, a large number of renown empirical papers that report sectoral EPP differences have addressed the issue by conducting additional investigation, for example by splitting samples according to firm size or age and by providing plausible rationalisations; see e.g. Aw and Hwang (1995), Aw et al. (2000), Farinas and Martin-Marcos (2007), Head and Ries (2003), or Merino (2004). ${ }^{2}$ The current paper takes a different direction.

\footnotetext{
${ }^{1}$ As has been pointed out by Syverson (2011), an understanding of the underlying drivers of productivity dispersion is essential for many policy areas such as competition policy or government measures aiming at promoting productivity growth in the economy. In parallel, the understanding of the EPP developed in this paper is an important stepping stone when thinking about effects of trade polices or the rational and targeting of export promotion policies.

${ }^{2}$ Similarly, ISGEP (2008) establishes and discusses intensively the identified size differences between country EPPs - in contrast much of the remaining literature are singlecountry studies (see the surveys of Greenaway and Kneller, 2007; Wagner, 2007, 2012; and Bernard et al., 2012). In particular, the implementation of different estimation strategies makes comparisons across studies difficult.
} 
We explore the link between heterogeneous firms trade theory and the empirical patterns of EPP magnitude. In doing so, the paper contributes on three frontiers. First, we provide a theoretical underpinning of why and how sectoral EPPs differ as driven by a number of sector-specific characteristics in an adapted Melitz (2003) model. Previous theoretical literature has - despite of deriving productivity rankings of exporters and non-exporters - not examined the theoretical EPP. Second, in an initial empirical investigation, we take the model literally and estimate a number of naive cross-sectional models. From these structural estimations we find that several of the deep parameters pinpointed in theory to determine the EPP are confirmed by the data. Thirdly, we link the model and first evidence into the empirical productivity literature and develop a proper empirical specification, that both confirms the robustness of our results, but more importantly demonstrates the importance and practicality of refining productivity comparisons. Moreover, we are able to identify new and sofar unreported empirical regularities, such as the importance of the elasticity of substitution for the size of EPP. These findings are highly relevant for future research. In sum, our theoretical end empirical findings offer convincing explanations for the size differences in EPPs that have been reported in the literature for almost two decades.

The paper conducts a number of steps in order to tackle the open questions surrounding the reported size differences of exporter productivity premia. First, we turn to theory. A simple thought experiment illustrates the task. Consider a standard heterogeneous firms trade model and add one extremely productive exporting firm. At first sight, this should increase the EPP. Yet, empirical EPP measures compare the group of exporters to nonexporters. Thus, in theory, via general equilibrium effects the addition of a highly productive firm toughens the exit and exporter cut-off and therefore changes the composition of firms in both groups. Hence, it becomes a nontrivial task to compute the overall effect on the EPP. Accordingly, we start out by computing the theoretical sectoral EPP in a symmetric two-country multi-sector version of a Melitz (2003) model with Pareto-distributed productivities. Thus we bring the model closer to what is actually examined in the empirical literature. In contrast, previous theoretical work has simply considered the rankings of firms according to productivity. Such a ranking implies that firms above the export threshold export and firms below do not export. While a positive sign for the EPP follows directly from this exercise, inference on the drivers of EPP magnitude is not provided. We resolve these issues and present predictions from theory addressing the relation of the deep (and empirically measurable) parameters of the model to the sectoral EPP. Theory predicts that a larger degree of heterogeneity in the productivity distribution of a sector and higher trade costs (both fixed and variable) imply a 
larger sectoral EPP. ${ }^{3}$ Furthermore, the model shows that smaller fixed costs of production correlate positively with the sector's EPP, while the effects from the intra-sector elasticity of substitution (i.e. product differentiation) are ambiguous.

Previous theoretical work by Schröder and Sørensen (2012) has investigated observable exporter productivity (in contrast to marginal productivity), both in a Melitz (2003) setting as well as in a Bernard et al. (2003) model. Their work asserts that the underlying distribution of marginal productivities should matter for the sign and size of the aggregated EPP. Yet, their focus is on individual firms' observable productivity and they fail to address the empirically relevant question of identifying the drivers of EPP magnitude. In contrast, the present paper's theoretical contribution is to derive the sectoral EPP and examine how this measure responds to changes in the deep parameters of the model.

Second, we take the predictions of the theory to the data. Based on 13 years of firm-level data for the universe of Danish firms, including destination codes, we are able to implement estimations of sectoral EPPs for 3-digit level industries. Initially, we take the model's nature literally and estimate a number of cross-sectional EPP models by simply pooling all observations and providing industry-level structural estimates. These admittedly naive estimations turn out to confirm the role and effect of fixed trade costs: sectors with higher fixed export costs feature larger EPPs. Most importantly, we establish that the variance in the underlying productivity distribution is decisive for the size of EPP realisations: sectors with a larger degree of heterogeneity display larger magnitudes of EPP. Furthermore, market power, that is a lower elasticity of substitution (or more differentiated products) which in theory has ambiguous effects - is in the data associated with larger EPPs. However, the theoretical prediction for variable trade costs is not confirmed by these estimations.

Subsequently, we develop a series of sophisticated empirical specifications exploring the full potential of our data. Here we introduce a series of additional empirical proxies for the industry-level parameters, include a wide range of controls and allow for dynamics and learning. We confirm the robustness of our results for a wide range of specifications and estimation techniques.

These theoretical and empirical findings are the first attempt to explain the cross-industry and cross-country differences in EPPs found in the liter-

\footnotetext{
${ }^{3}$ That the dispersion of the productivity distribution is one of the important fundamentals is already pointed out by Helpman et al. (2004) in the context of export channel choices, i.e. their investigation of the relation between direct exports and foreign affiliate sales in various destination markets.
} 
ature. In our data, once underlying industry characteristics (in particular the degree of firm heterogeneity - a measure available to every researcher working with firm-level data) are taken into account, then more than $30 \%$ of the observed variation in EPPs size differences is explained.

The remainder of the paper is structured as follows. Section 2 introduces and calculates the sectoral EPP in a two-country symmetric multi-sector Melitz (2003) model augmented with Pareto-distributed productivities. Section 3 presents our data and empirical set-up. Section 4 presents our empirical results, compares them to the theory and draws conclusions for future empirical research. Section 5 summarizes.

\section{Exporter Productivity Premia in Theory}

We derive exporter productivity premia in a symmetric two-country version of Melitz (2003). In line with the literature we only consider steady states and we only make two modifications to the workhorse model. First, in order to reflect cross-sectoral variation in EPP we rewrite the model to include $J$ heterogeneous sectors. This extension is only a matter of exposition. Second, to ensure tractability and transparency and to obtain clear-cut analytical predictions on how the EPP depends on industry-specific characteristics, we adopt the conventional assumption of productivities being Pareto-distributed. ${ }^{4}$

\subsection{Households}

A representative household supplies $L$ units of labour inelastically to the labour market and derives utility from consumption of different varieties from the $J$ sectors. The utility function of the household reads

$$
U=u\left(C_{1}, C_{2}, . ., C_{J}\right)
$$

where $C_{j}$ denotes the consumption of the sector $j$ specific composite consumption bundle. ${ }^{5}$ The composite consumption bundles are of the Dixit-

\footnotetext{
${ }^{4}$ For applications of the Pareto distribution within heterogeneous firms trade models, see e.g. Helpman et al. (2004) and Chaney (2008). Moreover, the Pareto approximates the distribution of productivity of firms found in empirical work (see e.g. Simon and Bonini, 1958; and more recently Axtell, 2001; and Luttmer, 2007) and resembles the empirical patterns we find for Danish firms at least for the right tail of the distribution, see Figure 1, Table 2 and Section 3.1.

${ }^{5}$ We assume that all first-order partial derivatives are positive, i.e. utility increases in all the sector-specific consumption bundles (defined by (1)).
} 
Stiglitz (1977) CES type

$$
C_{j}=\left(\int_{\omega \in \Omega_{j}}\left(c_{j}(\omega)\right)^{\frac{\sigma_{j}-1}{\sigma_{j}}}\right)^{\frac{\sigma_{j}}{\sigma_{j}-1}} \text { for } j=1,2, . ., J,
$$

where $c_{j}(\omega)$ denotes consumption of variety $\omega$ of sector $j, \Omega_{j}$ is the endogenously determined set of varieties (both domestic and foreign) from sector $j$ available to the household and $\sigma_{j}$ is the elasticity of substitution between any two varieties within sector $j$. Demand for variety $\omega$ of sector $j$ becomes

$$
c_{j}(\omega)=C_{j}\left(\frac{p_{j}(\omega)}{P_{j}}\right)^{-\sigma_{j}} \text { for } j=1,2, . ., J \text { and } \forall \omega \in \Omega_{j},
$$

where $p_{j}(\omega)$ is the price of variety $\omega$ of sector $j$ and $P_{j}$ is the price of buying one unit of the composite bundle $C_{j}{ }^{6}$

\section{$2.2 \quad$ Firms}

All $J$ sectors feature monopolistic competition. Accordingly, firms take the sector level variables $C_{j}$ and $P_{j}$ as given. Each firm only produces one unique variety $\omega$ within a single sector. Labour is the only input factor and remunerated at the economy wide wage rate $w$. Entry into a sector, i.e. inventing a new variety, is associated with sunk costs of $f_{e, j}$ units of labour. The creation of a new variety entails a variety-specific and fixed productivity, $\varphi_{j}(\omega)$. Realised variety-specific productivity is stochastic due to the random nature of research and development $(\mathrm{R} \& \mathrm{D})$ processes. We assume that productivities are drawn from known sector-specific Pareto distributions with location parameters $\varphi_{0, j}$ and shape parameters $k_{j} .{ }^{7}$ The cumulative distribution function thus reads

$$
G_{j}\left(\varphi_{j}(\omega)\right)=1-\left(\frac{\varphi_{j}(\omega)}{\varphi_{0, j}}\right)^{-k_{j}} \text { for } j=1,2, . ., J .
$$

Firms from a competitive fringe enter the industry until expected profits from entry equal the sunk costs of entry. Firms that decide to produce

${ }^{6}$ The price index reads

$$
P_{j}=\left(\int_{\omega \in \Omega_{j}}\left(p_{j}(\omega)\right)^{1-\sigma_{j}}\right)^{\frac{1}{1-\sigma_{j}}} \text { for } j=1,2, . ., J .
$$

${ }^{7}$ We impose the parameter restriction $k_{j}>\max \left(2, \sigma_{j}-1\right)$ in order to ensure finite variance of the productivity distribution and finite expected profits prior to entry. 
face fixed costs of production $f_{j}$ (units of labour). Accordingly, the labour requirement of a firm with productivity $\varphi_{j}(\omega)$ that produces $q$ units becomes $l_{j}\left(q \mid \varphi_{j}(\omega)\right)=\frac{q}{\varphi_{j}(\omega)}+f_{j}$. In addition, firms have the option to export. Exporting is subject to fixed export costs of $f_{j, x}$ units of labour and variable export costs of the iceberg type, i.e. firms must ship $\tau_{j}$ units for one unit to arrive.

Given the constant elasticity of demand, cf. (2), firms in each sector set prices as constant mark-ups on marginal costs implying that domestic (subscript $d$ ) and export market (subscript $x$ ) prices are given by

$$
\begin{aligned}
& p_{j, d}\left(\varphi_{j}(\omega)\right)=\frac{\sigma_{j}}{\sigma_{j}-1} \frac{w}{\varphi_{j}(\omega)} \\
& p_{j, x}\left(\varphi_{j}(\omega)\right)=\frac{\sigma_{j}}{\sigma_{j}-1} \frac{w \tau_{j}}{\varphi_{j}(\omega)} .
\end{aligned}
$$

Accordingly, reduced form profits in the domestic market and in the export market of a sector are given by

$$
\begin{aligned}
& \pi_{j, d}\left(\varphi_{j}(\omega)\right)=B_{j}\left(\varphi_{j}(\omega)\right)^{\sigma_{j}-1}-w f_{j} \\
& \pi_{j, x}\left(\varphi_{j}(\omega)\right)=B_{j}\left(\varphi_{j}(\omega)\right)^{\sigma_{j}-1} \tau_{j}^{1-\sigma_{j}}-w f_{j, x}
\end{aligned}
$$

where $B_{j} \equiv C_{j}\left(P_{j}\right)^{\sigma_{j}}\left(\frac{\sigma_{j}}{\sigma_{j}-1}\right)^{-\sigma_{j}} \frac{1}{\sigma_{j}-1}(w)^{1-\sigma_{j}}$ is a sector-specific demand component. It follows that profits increase in productivity $\varphi_{j}(\omega)$ and only firms with sufficiently high productivity find it profitable to enter a given market. Consequently, firms self-select according to productivity into exiters $\left(\varphi_{j}(\omega)<\varphi_{j, d}^{*}(\omega)\right)$, pure domestic non-exporters $\left(\varphi_{j, d}^{*}(\omega) \leq \varphi_{j}(\omega)<\right.$ $\left.\varphi_{j, x}^{*}(\omega)\right)$ and exporters $\left(\varphi_{j}(\omega) \geq \varphi_{j, x}^{*}(\omega)\right)$ where the exit thresholds, $\varphi_{j, d}^{*}(\omega)$, and export thresholds of a sector $\left(\varphi_{j, x}^{*}(\omega)\right)$ are defined by

$$
\begin{aligned}
& \pi_{j, d}\left(\varphi_{j, d}^{*}(\omega)\right)=0 \Leftrightarrow \varphi_{j, d}^{*}(\omega)=\left(\frac{w f_{j}}{B_{j}}\right)^{\frac{1}{\sigma_{j}-1}} \\
& \pi_{j, x}\left(\varphi_{j, x}^{*}(\omega)\right)=0 \Leftrightarrow \varphi_{j, x}^{*}(\omega)=\left(\frac{w f_{j, x} \tau_{j}^{\sigma_{j}-1}}{B_{j}}\right)^{\frac{1}{\sigma_{j}-1}} .
\end{aligned}
$$

We impose the parameter restriction $f_{j, x} \tau_{j}^{\sigma_{j}-1}>f_{j}$ which ensures that firms - in line with empirical evidence - partition into exporters and non-exporters.

\subsection{Theoretical EPP Predictions}

Within the above specification we are able to compute sectoral EPPs. In particular, we derive a theoretical EPP measure that in line with empirical 
measures compares the difference in average productivity between the group of exporters and the group of non-exporters relative to the average productivity of the group of non-exporters. Given CES consumption bundles, a sector's structure - and accordingly the sectoral EPP - only depends on variables specific to the sector in question and not on the values of all $B_{j}$ for $j=1,2, \ldots, J$ being determined in general equilibrium. The EPP in sector $j$ is defined as:

$$
P R_{j} \equiv \frac{E\left(\varphi_{j}(\omega) \mid \varphi_{j}(\omega) \geq \varphi_{j, x}^{*}\right)-E\left(\varphi_{j}(\omega) \mid \varphi_{j, d}^{*} \leq \varphi_{j}(\omega)<\varphi_{j, x}^{*}\right)}{E\left(\varphi_{j}(\omega) \mid \varphi_{j, d}^{*} \leq \varphi_{j}(\omega)<\varphi_{j, x}^{*}\right)} .
$$

By using the Pareto distribution given in (3), one can rewrite (6) as ${ }^{8}$

$$
P R_{j}=\frac{\left(\frac{\varphi_{j, d}^{*}}{\varphi_{j, x}^{*}}\right)^{-k_{j}}-1}{\left(\frac{\varphi_{j, d}^{*}}{\varphi_{j, x}^{*}}\right)^{-k_{j}+1}-1}-1 .
$$

We can now state:

Proposition 1. The theoretical exporter productivity premium, $P R_{j}$, in sector $j$ depends only on the sector variables $k_{j}, f_{j, x}, \tau_{j}, f_{j}$ and $\sigma_{j}$ and is given by

$$
P R_{j}=\frac{\left(\frac{f_{j, x} \tau_{j}^{\sigma_{j}-1}}{f_{j}}\right)^{\frac{k_{j}}{\sigma_{j}-1}}-1}{\left(\frac{f_{j, x} \tau_{j}^{\sigma_{j}-1}}{f_{j}}\right)^{\frac{k_{j}-1}{\sigma_{j}-1}}-1}-1 .
$$

Proof. The premium follows from evaluating (7) using the thresholds given by (4) and (5).

Proposition 1 implies a series of results on how the various sector variables affect the magnitude of a sector's EPP. ${ }^{9}$

Corollary 1. Sectors that are more heterogeneous in their productivity distribution (lower $k_{j}$, implying a higher productivity dispersion) have larger exporter productivity premia.

Corollary 2. Sectors that have higher fixed costs of exporting $\left(f_{j, x}\right)$ have larger exporter productivity premia.

\footnotetext{
${ }^{8}$ The derivation appears in a separate appendix, available upon request.

${ }^{9}$ The proofs of the Corollaries follow directly from the partial derivatives of the expression for the sector-specific productivity premium (8).
} 
Corollary 3. Sectors that have higher variable trade costs $\left(\tau_{j}\right)$ have larger exporter productivity premia.

Corollary 4. Sectors that have lower fixed costs of production $\left(f_{j}\right)$ have larger exporter productivity premia.

Corollary 5. The effect of the intra-sectoral elasticity of substitution $\left(\sigma_{j}\right)$ on the exporter productivity premia is ambiguous.

Corollaries 1 to 4 provide clear and potentially testable predictions on the drivers of EPP size differences. Obviously, the assumptions on the distribution function of productivity are important for these results. To illustrate: consider the effect of fixed export costs on the premium (Corollary 2). As is well known from the Melitz (2003) model, higher fixed export costs reduce the domestic exit threshold and increase the export threshold. The lower exit threshold ceteris paribus reduces the average productivity among non-exporters and thus increases the premium as more low-productive pure domestic firms appear in the sector. The higher export threshold has two opposing effects. On the one hand, it increases the average productivity among exporters and thus the EPP should increase. On the other hand, it increases the average productivity among non-exporters as the least productive exporters shift status and become non-exporters, which implies a reduction in the EPP. Thus, in general no clear-cut results are to be expected unless some structure on the productivity distribution is assumed. The Pareto distribution is particularly convenient in this respect, not just because we find some empirical support for its applicability to our firm-level data (see Figure 1 and Table 2), but also because its highly tractable properties imply that the EPP becomes a function of only two independent arguments, namely the ratio of the export threshold to the exit threshold and the shape parameter of the Pareto, cf. Equation (7). Following from this, it should be noted that the effect on the attractiveness of the export market relative to the domestic market underlies the results of Corollaries 2, 3 and 4 .

To understand Corollary 1 , note that the degree of heterogeneity increases (higher productivity dispersion) when the right tail of the distribution has more mass (lower $k_{j}$ ). More mass in the tail in turn increases the density among highly productive firms - both exporters and non-exporters. However, the effect is less pronounced for non-exporters because their productivity distribution, unlike that of exporters, is right-truncated. Hence, the EPP increases with the degree of heterogeneity.

Finally, our findings on the drivers of EPP size differences - even though cast in a multi-sector interpretation - translate to cross-country EPP size differences. In a multi-country model, for example, a country with a more 
homogeneous productivity distribution would display a lower EPP compared to countries with more heterogeneity among their firms.

\section{Data and Empirical Estimation Strategies}

In line with the theoretical foundation outlined in Section 2, our empirical focus lies on sectoral EPPs. ${ }^{10}$ Here we pursue two distinct approaches. First, we take the theoretical model directly to the data in the sense that we obtain industry-level structural estimates of the parameters shown in Section 2 to affect EPP. We include these parameters in a simple cross-sectional model of EPP formation pooling over all observations. Thus, in this naive specification we stay true to the model and only exploit variation in the data across firms. We analyse how the empirically observed EPP correlate with the estimated sector-level parameters and compare with our theoretical predictions. Secondly, we develop a series of sophisticated empirical specifications that exploit the full potential of our data. In this step we depart from the specific structure of our theoretical model. For example, in line with the current literature we provide inter alia firm-level fixed effect estimates, thus focusing on within-firm variation to identify effects. Moreover, we bring in a wide range of established controls and use various empirical proxies instead of structural estimates for our EPP drivers to confirm the robustness of our results. The analysis is conducted for a range of empirical estimation methods. Thus, in these estimates we integrate our newly proposed mechanisms into the current state of the art for empirical work on exporter productivity.

Finally, Wagner $(2007,2012)$ provides comprehensive surveys of the empirical literature and finds almost universal support for the view that the positive EPPs found in the literature are caused by the most productive firms self-selecting into export markets (for other recent studies see e.g., López, 2009; Kneller and Pisu, 2010; Vinzenzo and Wagner, 2011). In the same spirit, Bernard et al. (2007, p. 111) argue that: "Results from virtually every study across industries and countries confirm that high productivity precedes entry into export markets". At the same time, there is some empirical support for the hypothesis that firms become more productive as a consequence of exporting (see e.g., De Loecker, 2007; Kneller and Pisu, 2010; Marin and Voigtländer, 2013). Of course the two hypotheses, self-selection and learning through exports, are not mutually exclusive. Accordingly, we also evaluate whether our results are robust to potential reversed causality.

\footnotetext{
${ }^{10}$ An alternative research design could examine cross-country EPP variations, however, data collection and coding differ across countries, and even the comprehensive study of ISGEP (2008) arrives at only 14 comparable countries.
} 


\subsection{Data}

Our data set consists of Danish firm-level data provided by Statistics Denmark for the period 1995-2007 and combines destination-specific export information with business account information. Starting from the universe of all Danish firms, we exclude non-manufacturing firms and firms with missing sales or total sales below DKK 100,000 (about USD 17,000) per year. Thus, we only exclude extremely small if not erroneous firms but abstain from trimming the sample with respect to the number of employees, output, productivity or other firm characteristics to maintain information on essentially all active manufacturing firms. The resulting sample is composed of 40,924 firms, of which 9,736 exporters sell to a total of 168 countries. The central variables capital and labour are measured as firms' total fixed assets and as firms' number of full-time equivalent employees, respectively. ${ }^{11}$

Sectoral information is calculated at the 3-digit level, giving us 99 sectors over 13 years with active exporters to compare and analyse sectoral EPP differences across. Furthermore, to quantify sectoral iceberg trade costs we estimate sectoral gravity models merging destination-specific data on GDP, GDP per capita, distance and bilateral indicators of physical and political separation provided by Head et al. (2010) and extrapolated until 2007. Finally, we also use OECD maritime transport costs data. Descriptive statistics on all relevant variables are provided in Table 1.

To access how closely the productivity distribution for Denmark resembles a Pareto distribution, we transform Equation (3) into logs and obtain a convenient linear regression model that allows us to evaluate the goodness of fit of the Pareto distribution:

$$
\ln \left(1-\widehat{G}_{j}\left(\varphi_{i j t, T F P}\right)\right)=\alpha-k_{j} \ln \varphi_{i j t, T F P}+\epsilon_{i j t}
$$

with $\widehat{G}_{j}\left(\varphi_{i j t, T F P}\right)$ denoting the empirical distribution function of productivity in industry $j, i$ denoting firm and $t$ time.

Figure 1 depicts plots of $\ln (1-\widehat{G}(\varphi))$ against $\ln \varphi$ pooled over all industries, firms and years and the corresponding fitted lines and $R^{2} \mathrm{~s}$ as goodness of fit measures with $\varphi$ being constructed from TFP regressions. ${ }^{12}$ If productivity indeed follows a Pareto distribution, the depicted log-log relationship should follow a linear function. As can be seen, a linear function provides a fairly poor fit when considering all firms. However, when ordering firms according

\footnotetext{
${ }^{11}$ Part-time workers receive a weight of 0.5 .

${ }^{12}$ Note that in our naive specification we assume - in line with the theoretical model - that labour is the only production factor. Obviously in our later empirical analysis, and thus our TFP measures, we allow for capital and intermediate inputs as additional production factors. Our preferred productivity measure is total factor productivity.
} 
Table 1: Descriptive Statistics

\begin{tabular}{|c|c|c|c|c|c|c|}
\hline & Mean & $\mathrm{SD}$ & Min & Max & Obs. & $\begin{array}{c}\text { missing/ } \\
\text { implausible }\end{array}$ \\
\hline \multicolumn{7}{|l|}{ Firm variables } \\
\hline Log value added & 13.97 & 1.95 & 6.91 & 23.24 & 255219 & \\
\hline Log labour & 1.49 & 1.51 & 0.00 & 9.44 & 255219 & \\
\hline Log capital & 13.62 & 1.98 & 6.91 & 24.18 & 251034 & 4185 \\
\hline Exporter dummy & 0.24 & 0.43 & 0.00 & 1.00 & 255219 & \\
\hline Importer dummy & 0.23 & 0.42 & 0.00 & 1.00 & 255219 & \\
\hline \multicolumn{7}{|l|}{ Industry variables $V$} \\
\hline Struct. estimate of prod. heterog. $k^{-1}$ & 0.84 & 0.14 & 0.01 & 4.24 & 255219 & \\
\hline Log average export sales & 16.60 & 1.22 & 8.81 & 20.79 & 255056 & 163 \\
\hline Log number of destinations & 1.85 & 0.67 & 0.00 & 3.58 & 255097 & 122 \\
\hline Log struct. estimate of fixed export costs $f_{x}$ & 14.32 & 1.16 & 5.82 & 18.88 & 239551 & 15668 \\
\hline Share of foreign sales of exporters & 24.43 & 12.83 & 0.02 & 174.65 & 255056 & 166 \\
\hline Gravity model abs. value of distance par. & 1.45 & 0.84 & 0.12 & 4.39 & 231498 & 23721 \\
\hline Maritime ad-valorem transport costs & 0.03 & 0.02 & 0.00 & 0.16 & 251722 & 3497 \\
\hline Log struct. estimate of iceberg costs $\tau$ & 3.71 & 2.59 & 0.00 & 557.46 & 236263 & 18956 \\
\hline Capital intensity & 0.56 & 0.39 & 0.02 & 10.40 & 255142 & 77 \\
\hline Log average domestic sales & 16.28 & 0.92 & 10.99 & 21.16 & 255211 & 8 \\
\hline Log struct. estimate of fixed production costs $f$ & 14.38 & 1.33 & 9.61 & 20.91 & 239551 & 15668 \\
\hline Struct. estimate of elasticity of substitution $\sigma$ & 1.59 & 0.12 & 1.02 & 31.38 & 255219 & \\
\hline
\end{tabular}

to their productivity and subsequently excluding the bottom 5 th, 10 th and 25th percentile, the linear fit between $\ln (1-\widehat{G}(\varphi))$ and $\ln \varphi$ improves dramatically. Thus - in line with previous literature - the right tail of the actual productivity distribution has the best match to the Pareto. We repeat this exercise and estimate per sector Pareto functions reporting on the spread in $R^{2}$ s found among our 99 industries in Table 2. Again, by excluding the lowest productivity firms the $R^{2}$ values improve.

\section{Table 2: Fit of Pareto Distribution by Industry}

\begin{tabular}{lccc}
\hline & Mean & Standard Deviation & Observations \\
& & & \\
$R^{2}$ All Firms & 0.76 & 0.07 & 99 \\
$R^{2}$ excluding 5th percentile & 0.83 & 0.06 & 99 \\
$R^{2}$ excluding 10th percentile & 0.86 & 0.05 & 99 \\
$R^{2}$ excluding 25th percentile & 0.92 & 0.05 & 99 \\
\hline
\end{tabular}

\subsection{Empirical Models}

As always when taking theory to the data, it is important to acknowledge the wide range of forces that affect real countries and firms' trading patterns, 


\section{Figure 1: Productivity Distribution Pooled over all Industries}
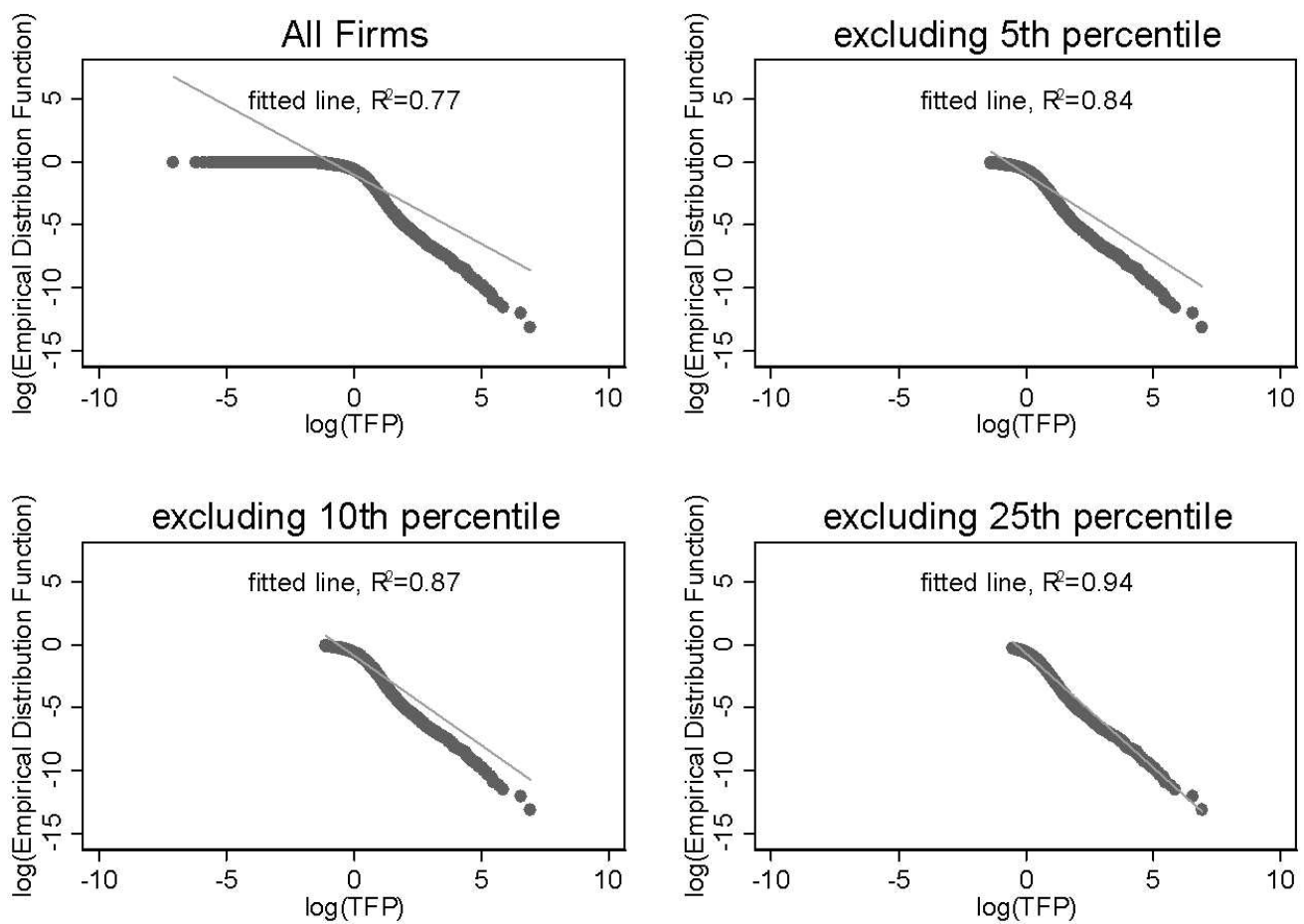

but that have been conveniently ignored in the theoretical set-up. For example, alternative drivers of trade, such as comparative advantage or effects stemming from other country asymmetries, are all absent in our theoretical EPP results, but will matter in the data. Furthermore, importer status absent in the theory - clearly matters in reality and must be controlled for in our estimations (see Bernard et al. 2007, 2012). Also, as Eaton et al. (2012) have pointed out recently, the conventional modelling of firms as points on a continuum creates additional - potentially costly - discrepancies between theory and data. Finally, time and timing - an illusive concept when studying steady state equilibria as in Section 2 - will clearly be present in our firm-level data.

Against this backdrop, we pursue two separate approaches in our empirical work. First, we take the theory at face value, thus taking the workhorse model of heterogeneous firms trade and seeing if it can shed light on the stylized fact of substantial cross-sectoral EPP size differences. It turns out that it can. In a second step we integrate the insights and check their robustness in more sophisticated estimation specifications, representing a wide range of 
state-of-the-art methodologies and thus illustrate the empirical possibilities that emerge from our findings.

\subsubsection{The Naive Empirical Models}

For this part we stay as close as possible to the theory of Section 2 and estimate a naive cross-sectional model, where we pool over all observations and only allow for industry-level fixed effects but ignore firm heterogeneity (other than what is reflected in exporter status). Moreover, for this specification we claim that labour constitutes the only production factor. As pointed out in, e.g., Syverson $(2004,2011)$ productivity measures are constructed based on sales and not physical quantities and, thus, are not only driven by firm efficiency but can be affected by demand shocks and firms' market power. To reflect on this and in order to provide some simple robustness, we also look at size differences between exporters and non-exporters (number of full-time employees) in addition to the EPP. Note, that for the theory from Section 2 all corollaries of the model hold with respect to the size premium of exporters.

Thus the naive model reads:

$$
\ln Z_{i j}=\alpha_{j}+\delta \operatorname{Exp}_{i}+\eta V_{j}+\theta\left(\operatorname{Exp}_{i} V_{j}\right)+\kappa_{i j}
$$

where $Z$ either is labour productivity $\frac{Y_{i}}{L a b_{i}}$ with $Y$ denoting value added, or firm size in terms of the number of full-time employees $L a b$. Our main variable of interest, exporter status, is represented by the dummy variable Exp while $V_{j t}$ represents industry $j$ specific characteristics as outlined in Section 2 , for example the degree of heterogeneity in productivity among the firms in the industry with $i \in j$. The parameter $\alpha_{j}$ refers to an industry fixed effect. Thus, the exporter premium is identified through cross-sectional variation of exporters' and non-exporters' productivity (or size) within industry $j$. The error term $\kappa_{i j}$ is allowed to be heteroscedastic and correlated within 3-digit industries $j$. In order to embed Corollaries 1 to 5 , we obtain structural estimates of industry characteristics $V_{j}$ by computing moments from the model in Section 2 and equating these moments to their empirical counterparts.

The degree of heterogeneity in the productivity distribution is measured by the industries standard deviation of $\log$ labour productivity. ${ }^{13}$ This is a standard measure of productivity dispersion (see e.g. Bernard et al., 2003)

\footnotetext{
${ }^{13}$ Technically, we could also use an estimated shape parameter $k_{j}$ directly. However, since the data only in part resemble a Pareto distribution, the standard deviation measure is more appropriate. It allows us to use the entire universe of firms, instead of omitting the lowest productivity firms in order to ensure the Pareto-ness of the productivity distribution (see Table 2).
} 
and in our theoretical model this measure reads ${ }^{14}$

$$
\operatorname{Std}\left(\log \varphi_{j}(\omega) \mid \varphi_{j}(\omega) \geq \varphi_{j, d}^{*}\right)=k_{j}^{-1} .
$$

Accordingly, the relation between the empirical EPP and productivity dispersion is directly comparable to Corollary 1 and we expect sectors with a higher degree of heterogeneity in productivity to command larger EPP.

Next, we move to Corollaries 2 to 5 . In contrast to our measure of $k_{j}$, directly observable empirical measures corresponding to $\sigma_{j}, f_{j}, f_{j, x}$ and $\tau_{j}$ are somewhat less straightforward to obtain.

For the elasticity of substitution $\sigma_{j}$ we utilise that the coefficient of variation for sales/revenue of domestic firms on the domestic market reads

$$
C V\left(r_{j, d}\left(\varphi_{j}(\omega)\right) \mid \varphi_{j}(\omega)>\varphi_{j, d}^{*}\right)=\frac{\sigma_{j}-1}{\sqrt{k_{j}\left(k_{j}-2\left(\sigma_{j}-1\right)\right)}}
$$

and given the estimate of $k_{j}$ we obtain an estimate of $\sigma_{j}$. Although the theory was ambiguous on the effect of $\sigma_{j}$ on the EPP, we look for empirical regularities in the data.

For the fixed costs of production $f_{j}$, we exploit that average domestic sales across all domestic firms read

$$
\bar{r}_{j, d}=\frac{\sigma_{j} k_{j}}{k_{j}-\left(\sigma_{j}-1\right)} w f_{j}
$$

and given the estimates on $k_{j}$ and $\sigma_{j}$ we obtain an estimate of $w f_{j}$, where $w$ is constant across sectors and thus not important for explaining sectoral variation in the EPP. ${ }^{15}$ In terms of a theoretical prediction we expect that higher fixed costs of production are associated with a lower sectoral EPP (Corollary 4).

Turning to the export costs, we have to be slightly more careful as we have a two-country theoretical model whereas in the data the Danish firms export to several countries with different export barriers. For our purpose the important division of firms is between exporters and non-exporters and by making the crude assumption that all firms in all industries enter the same export destination first, we can exploit the performance of Danish firms on that destination to estimate the trade barriers relevant for becoming an exporter or not and thus relevant for the EPP. As Germany is a neighbour to Denmark and also the most important export destination for Danish exports

\footnotetext{
${ }^{14}$ Our derivations of this and the other moments below are elaborated further in a separate appendix, available upon request.

${ }^{15}$ Where necessary, we correct for time variation in $w_{t}$ by transforming structural estimates of fixed costs into constant prices.
} 
(accounting for $16 \%$ of manufactured goods exports at the end of our sample period), we have chosen Germany as this first export destination. ${ }^{16}$ For the fixed trade costs we exploit that average sales of Danish firms in sector $j$ to the German market read

$$
\bar{r}_{j, x}^{\text {Germany }}=\frac{\sigma_{t} k}{k-\left(\sigma_{j}-1\right)} w f_{j, x}^{\text {Germany }}
$$

and given the estimates on $k_{j}$ and $\sigma_{j}$ we obtain an estimate of the fixed trade costs $w f_{j, x}^{\text {Germany }}$. We expect to find a positive relation between this measure of fixed export costs and the sectoral EPP (Corollary 2).

For the iceberg trade costs we utilise that the share of firms exporting to Germany reads

$$
s_{j, x}^{\text {Germany }}=\left(\frac{f_{j, x}^{\text {Germany }}\left(\tau_{j}^{\text {Germany }}\right)^{\sigma_{j}-1}}{f_{j}}\right)^{\frac{-k_{j}}{\sigma_{j}-1}}
$$

and given the estimates of $w f_{j, x}^{G e r m a n y}, w f_{j}, \sigma_{j}$ and $k_{j}$ the estimate of the iceberg trade costs $\tau_{j}^{\text {Germany }}$ follows. According to Corollary 3 higher variable trade costs should result in larger EPP.

\subsubsection{Full Empirical Models}

In this section we abandon the constraints implied by the theory and bring our empirical analysis closely in line with a wide range of empirical models. Most importantly, we exploit now the fact that the same firm may be observed for several time periods and that the estimated industry variables/parameters will be time-varying. Furthermore, we allow for firmspecific and time-specific unobserved heterogeneity. Moreover, we extend our analysis by employing empirical proxies instead of structural estimates for the industry-level parameters in order to evaluate whether our findings also apply when not relying on the exact structure of our stylized modeling framework. As alternatives to some of the structural estimated sectoral characteristics we consider the following measures/proxies. ${ }^{17}$ For the fixed export

\footnotetext{
${ }^{16}$ Alternatively one could also construct a trade weighted average measure of export costs across all destinations. However, as international trade in itself is a function of export costs we abstain from this exercise.

${ }^{17}$ In the case of $V \equiv k^{-1}$ the moment applied to obtain the structural estimate of the productivity heterogeneity coincides with a standard measure of productivity heterogeneity, namely the standard deviation of log productivity, see e.g. Bernard et al. (2003), and therefore no alternative proxies are considered. Similarly, we could not obtain meaningful empirical proxies for $\sigma$ and thus use our structural estimate throughout the paper.
} 
costs, $f_{j t, x}$, we use (i) the per sector average of firms' foreign sales volume indicating minimum efficiency of scale of the export activity. Furthermore, we use (ii) the sector average of number of destinations served per firm as an alternative proxy for $f_{j t, x}$ - with more destinations implying larger initial (destination-unspecific) fixed export costs. We proxy variable iceberg trade costs, $\tau_{j t}$, by (i) the average share of foreign sales in total sales of exporters in an industry, whereby a smaller share stems from higher variable trade costs. In addition, we provide (ii) a gravity-based estimation of sectoral transport costs. The data allows us to estimate separate gravity equations at the 3 -digit industry level and we stipulate that sectors with lower gravity coefficients i.e. less responsive to distance - have lower trade costs. ${ }^{18}$ As yet another measure of iceberg trade costs we obtain (iii) ad-valorem trade costs for manufactured goods from the OECD maritime transport costs database at the 2-digit level of the harmonised system focusing on container shipments and we obtain 3-digit industry-level transport cost measures by weighting with firms' respective export values. Naturally, maritime transport cost measures can only reflect export costs for sea transport and thus disregard air fright and trade costs within Europe. Nevertheless, we use the measure to test for the robustness of our findings. We proxy the fixed costs of production, $f_{j t}$, by (i) the capital intensity of domestic firms measured as the value of fixed assets over output. Moreover, we use (ii) the sectoral average of firms' domestic sales; whereby a larger scale indicates larger fixed costs.

We first obtain firm-level total factor productivity from estimating the following production function separately for each and every 3-digit industry $j$ with $i \in j$ :

$$
\ln Y_{i t}=\alpha_{i}+\beta_{c j} \ln C a p_{i t}+\beta_{l j} \ln L a b_{i t}+\beta_{y j} Y e a r_{t}+\iota_{i t},
$$

Cap representing the input factor capital and, and Year ${ }_{t}$ denoting a full set of time dummies to capture macroeconomic shocks. Firm-specific unobserved characteristics are captured by $\alpha_{i}$ and are assumed to be constant over time and the error term $\iota_{i t}$ is assumed to be i.i.d. Our firm- and time-specific total

\footnotetext{
${ }^{18}$ We follow Silva and Tenreyro (2006) and estimate Poisson pseudo-maximum-likelihood gravity models. Our model controls for partner country GDP and GDP per capita, firm size, distance, common currency, regional trade agreements, destination country WTO membership, and common border.
} 
factor productivity measure $T F P_{i t}$ is then constructed as: ${ }^{19}$

$$
\ln T F P_{i t}=\ln y_{i t}-\hat{\beta}_{c j} \ln C a p_{i t}-\hat{\beta}_{l j} \ln L a b_{i t} .
$$

To quantify the sectoral EPP, we proceed by estimating variants of the following baseline specification:

$$
\begin{aligned}
\ln T F P_{i t} & =\gamma_{i}+\zeta I m p_{i t}+\delta \operatorname{Exp}_{i t}+\eta V_{j t} \\
& +\theta\left(\operatorname{Exp}_{i t} V_{j t}\right)+\pi_{t} \text { Year }_{t}+\epsilon_{i t}
\end{aligned}
$$

Different from authors such as Bustos (2011) who jointly model technology upgrading and export selection after trade liberalisation or De Loecker (2007) who is concerned with learning through exporting, our empirical approach strictly focuses on the selection of firms into exporting. Accordingly, EPP differences across industries are here directly related to Corollaries 1 to 5 that have been obtained within a Melitz (2003) type framework only featuring selection. However, following the findings presented in Bernard et al. (2007, 2012), our model includes an indicator variable for importer status, Imp, which is not explicitly modeled in Melitz (2003). ${ }^{20}$

Including firm fixed effects $\gamma_{i}$ in our main specification implies that the exporter productivity premium is identified through within-firm variation in export status and TFP combined with cross-section and time variation in industry characteristics $V$ reflected in the interaction term. The remaining error term $\epsilon_{i t}$ is allowed to be heteroscedastic and correlated within 3-digit industries. Since firms do not switch between industries in our data, we do not include industry fixed effects.

We also estimate a specification that allows for time-changing firm-specific shocks $\alpha_{i t}$ in Equation (16). To do so, we follow De Loecker (2007) and estimate the model in an extended Olley and Pakes (1996) framework allowing export status to affect firms' investment decisions and correcting for selection through firm exit. However, we do not apply difference in difference

\footnotetext{
${ }^{19}$ As many studies rely on simple labour productivity measures, we also, for completeness, evaluate the labour productivity premium of export status estimating the following model:

$$
\ln \left(\frac{Y_{i t}}{\operatorname{Lab}_{i t}}\right)=\alpha_{i}+\zeta \operatorname{Imp}_{i t}+\delta \operatorname{Exp}_{i t}+\eta V_{j t}+\theta\left(\operatorname{Exp}_{i t} V_{j t}\right)+\pi_{t} \text { Year }_{t}+\epsilon_{i t} .
$$

${ }^{20}$ Note that in contrast to numerous empirical studies (e.g. Máñez et al., 2008; ISGEP, 2008) we do not control for firm size or the factor content of production in terms of skilled labour as we consider them to follow endogenously from firms' productivity draw and the respective selection into exporting.
} 
matching techniques as in De Loecker (2007) as we are interested in the selection process into exporting and not in identifying learning effects from exporting. ${ }^{21}$

Clearly, the full empirical framework departs very much from the theory outlined in Section 2. While Olley and Pakes (1996) assume firms to invest in their future productivities, in the Melitz framework firms merely make a one time productivity draw. Despite this discrepancy we nevertheless employ the Olley and Pakes estimator since it has become a standard method widely used in the empirical literature. To further test for the robustness of our findings, we estimate a difference-in-difference specification of (18) that allows for firm-specific productivity trends that may determine selection into exporter status. Accordingly, in this specification we compare exporting firms to non-exporting firms that before exporting were on the same productivity trajectory. Finally, in order to rule out that our findings are driven by the previously discussed potential reversed causality, i.e. by learning through exporting instead of self-selection, we also estimate a variant of (18) using $\ln T F P_{i t-3}$ as the dependent variable (see Appendix for details).

According to the above models, the exporter productivity premium expressed in per cent is:

$$
P R_{j t}=\left(e^{\delta+\theta V}-1\right) * 100 .
$$

Hence, we capture how the exporter productivity premia vary according to industry characteristics $V$ as predicted by theory. Obviously, our estimations serve to reflect upon the theory and remain descriptive in nature since; in order to avoid multicollinearity, we do not control simultaneously for all considered industry characteristics.

\section{Results}

We first focus on how EPP varies with the structural estimates of industry characteristics obtained in Equations (11)-(15) within our naive model that ignores the time dimension of the data and disregards firm-level unobserved heterogeneity (see Equation 10). To insure that our structural estimates are well defined, we constrain the sample to observations for which all structural estimates of industry characteristics are in line with what is theoretically feasible. That is, we excluded observations for which structural estimates

\footnotetext{
${ }^{21}$ Our empirical framework readily allows for alternative structural estimation techniques as proposed in, e.g., Ackerberg et al. (2006). However, our primary interest does not lie in the absolute size of EPP but in the pattern of EPP across industry characteristics $V$ which, as will be seen in Table 3, is robust to the choice of estimation technique.
} 
of fixed costs $\left(f_{j t}, f_{j t, x}\right)$ are negative and for which iceberg costs $\left(\tau_{j t}\right)$ are smaller than one (see descriptives in Table 1). ${ }^{22}$

We contrast these naive estimates with the findings of more elaborate empirical models that make full use of all dimensions in the data and allow for firm-specific and time-specific unobserved heterogeneity and where applicable employ empirical proxies for industry characteristics abstaining from applying common constraints to the sample (see Table 4). ${ }^{23}$

To save space we only report the estimated EPPs, but we do not report the 58 underlying econometric estimations that generate the EPPs in Tables 3 and 4. According to Equation (19), the EPP is allowed to differ along 3-digit industry characteristics $V$. For this reason we present EPPs calculated at the mean, the bottom decile, the median, and the top decile of the respective estimate of industry characteristic $V$ and perform a Wald test on the $H_{0}$ that the EPPs for the top and bottom decile are equal.

First, focussing on the structural estimate regarding industry-level productivity heterogeneity $k_{j}^{-1}$ reported in Panel (1) of Table 3, we find the pattern predicted by Corollary 1 . In industries where firms are most homogeneous in terms of productivity, exporting firms experience a size premium of $486 \%$ and a labour productivity premium of $61 \%$. In contrast, in the industries with the highest productivity heterogeneity exporter status yields a size premium of $640 \%$ and a productivity premium of $103 \%$. Importantly, while this pattern is striking and in line with our theory, the absolute magnitude of the size and productivity premium is implausibly high. ${ }^{24}$ However, when utilizing the time dimension of the data and addressing non-random unobserved heterogeneity that was ignored in the simple model, the magnitude of EPPs becomes much more in line with previous findings from the empirical literature.

\footnotetext{
${ }^{22}$ This excludes 18,956 observations from the analysis. Feasibility constraints on $k^{-1}$ and $\sigma$ were not binding.

${ }^{23}$ Note that the available number of observations varies with the different estimation techniques. Furthermore, due to item non-response with respect to $V$, the models vary slightly in the number of observations. Since the focus of this exercise is on the patterns outlined in Corollaries 1 to 5, we do not restrict the sample to be common across all analysed dimensions of $V$. Table 1 gives an overview of missing or implausible observations for $V$.

${ }^{24}$ Identification in this first simple model is through the cross-sectional variation between exporters and non-exporters and since we do not curtail the universe of Danish firms but, different from e.g. ISGEP (2008), even include very small unproductive and typically non-exporting firms, this generates large premia.
} 


\title{
Table 3: EPP and size premium with structural estimates of $V$
}

\author{
Mean Bottom Decile Median Top Decile Wald-Test Obs. Firms \\ Top=Bottom
}

\section{EPP in \%}

\begin{tabular}{|c|c|c|c|c|c|c|}
\hline \multicolumn{7}{|c|}{ Corollary $1: \mathrm{V} \equiv$ Structural estimate of productivity heterogeneity $k_{j t}^{-1}$} \\
\hline $\begin{array}{c}75.63 * * * \\
(4.21)\end{array}$ & $\begin{array}{c}60.65 * * * \\
(4.67)\end{array}$ & $\begin{array}{c}70.56 \text { *** } \\
(3.82)\end{array}$ & $\begin{array}{c}102.73^{* * *} \\
(11.56)\end{array}$ & $\begin{array}{l}\mathrm{F}=9.50^{* * *} \\
\mathrm{p}=0.0027\end{array}$ & 236263 & 40262 \\
\hline \multicolumn{7}{|c|}{ Corollary $2: \mathrm{V} \equiv \log$ structural estimate of fixed export costs $f_{i t, a}$} \\
\hline $\begin{array}{c}75.00 \text { *** } \\
(4.43)\end{array}$ & $\begin{array}{c}59.98 * * * \\
(4.53)\end{array}$ & $\begin{array}{c}73.06 \text { *** } \\
(4.18)\end{array}$ & $\begin{array}{c}88.89 * * * \\
(7.64)\end{array}$ & $\begin{array}{l}\mathrm{F}=10.49^{* * *} \\
\mathrm{p}=0.0017\end{array}$ & 236263 & 40262 \\
\hline \multicolumn{7}{|c|}{ Corollary 3: $\mathrm{V} \equiv \log$ structural estimate of iceberg costs $\tau_{j t}$} \\
\hline $\begin{array}{c}77.88 * * * \\
(5.10)\end{array}$ & $\begin{array}{c}71.78^{* * *} \\
(4.01)\end{array}$ & $\begin{array}{c}77.08 * * * \\
(4.81)\end{array}$ & $\begin{array}{c}85.44 * * * \\
(8.85)\end{array}$ & $\begin{array}{l}\mathrm{F}=2.65 \\
\mathrm{p}=0.1067\end{array}$ & 236263 & 40262 \\
\hline \multicolumn{7}{|c|}{ Corollary 4: $\mathrm{V} \equiv \log$ structural estimate of fixed production costs $f_{j t}$} \\
\hline $\begin{array}{c}75.63 * * * \\
(5.17)\end{array}$ & $\begin{array}{c}64.89 * * * \\
(6.69)\end{array}$ & $\begin{array}{c}74.64 * * * \\
(5.21)\end{array}$ & $\begin{array}{c}83.46 * * * \\
(5.76)\end{array}$ & $\begin{array}{l}\mathrm{F}=7.30^{* * *} \\
\mathrm{p}=0.0082\end{array}$ & 236263 & 40262 \\
\hline \multicolumn{7}{|c|}{ Corollary 5:V $\equiv$ Structural estimate of elasticity of substitution $\sigma_{j t}$} \\
\hline $\begin{array}{c}74.99 * * * \\
(4.27)\end{array}$ & $\begin{array}{c}102.41 \text { *** } \\
(12.06)\end{array}$ & $\begin{array}{c}69.92 * * * \\
(4.18)\end{array}$ & $\begin{array}{c}57.88 * * * \\
(6.17)\end{array}$ & $\begin{array}{l}\mathrm{F}=7.79^{* * *} \\
\mathrm{p}=0.0064\end{array}$ & 236263 & 40266 \\
\hline
\end{tabular}

Size premium (in terms of full-time employees) in \%

Corollary 1:V $\equiv$ Structural estimate of productivity heterogeneity $k_{j t}^{-1}$

\begin{tabular}{|c|c|c|c|c|c|c|}
\hline $\begin{array}{c}541.09 * * * \\
(32.83)\end{array}$ & $\begin{array}{c}486.79 * * * \\
(41.84)\end{array}$ & $\begin{array}{c}522.69 * * * \\
(34.68)\end{array}$ & $\begin{array}{c}639.22 * * * \\
(51.96)\end{array}$ & $\begin{array}{l}\mathrm{F}=5.14^{* * *} \\
\mathrm{p}=0.0256\end{array}$ & 36263 & 40262 \\
\hline \multicolumn{7}{|c|}{ Corollary $2: \mathrm{V} \equiv \log$ structural estimate of fixed export costs $f_{j t, x}$} \\
\hline $\begin{array}{c}528.25 * * * \\
(27.08)\end{array}$ & $\begin{array}{c}412.02 * * * \\
(36.63)\end{array}$ & $\begin{array}{c}512.49 \text { *** } \\
(27.23)\end{array}$ & $\begin{array}{c}647.76 \text { *** } \\
(42.43)\end{array}$ & $\begin{array}{l}\mathrm{F}=16.36^{* * *} \\
\mathrm{p}=0.0001\end{array}$ & & 40262 \\
\hline \multicolumn{7}{|c|}{ Corollary 3:V $\equiv$ Log structural estimate of iceberg costs $\tau_{j t}$} \\
\hline $\begin{array}{c}544.43 * * * \\
(34.13)\end{array}$ & $\begin{array}{c}575.67 * * * \\
(35.54)\end{array}$ & $\begin{array}{c}548.40 * * * \\
(33.27)\end{array}$ & $\begin{array}{c}509.04 * * * \\
(50.01)\end{array}$ & $\begin{array}{l}\mathrm{F}=1.59 \\
\mathrm{p}=0.2105\end{array}$ & 23 & 40262 \\
\hline
\end{tabular}

Corollary $4: \mathrm{V} \equiv \log$ structural estimate of fixed production costs $f_{j t}$

$\begin{array}{cccclrl}525.01^{* * *} & 382.44^{* * *} & 510.65 * * * & 647.32^{* * *} & \mathrm{~F}=18.36^{* * *} & 236263 & 40262 \\ (30.79) & (47.12) & (31.77) & (38.37) & \mathrm{p}=0.0000 & & \end{array}$

\begin{tabular}{ccccccc} 
Corollary 5:V & Structural estimate of elasticity of substitution $\sigma_{j t}$ \\
$538.65 * * *$ & $641.51 * * *$ & $519.65 * * *$ & $474.66^{* * * *}$ & $\mathrm{~F}=6.14^{* *}$ & 236263 & 40262 \\
$(33.23)$ & $(48.93)$ & $(35.43)$ & $(44.46)$ & $\mathrm{p}=0.0150$ & & \\
\hline
\end{tabular}

Notes: Standard errors in parentheses. ${ }^{*}, * *, * * *$ statistically significant at the $10 \%$, the $5 \%$, the $1 \%$ levels, respectively. No controls for unobserved heterogeneity, $V$ collapsed to industry averages. 
Still and most importantly, irrespective of the estimation technique the identified pattern with respect to industry-level productivity dispersion $k_{j t}^{-1}$ holds (see Panel (1) of Table 4). For instance, applying a baseline TFP model (18) we find that in industries where firms are most homogeneous in terms of productivity, exporting firms experience a productivity premium of $13 \%$. In contrast, in the industries with the highest productivity heterogeneity exporter status yields a productivity premium of $27 \%$. No matter whether we base our estimates on simple labour productivity measures, an OlleyPakes model specification accounting for firm- and time-specific shocks, or the difference-in-difference model, EPPs increase with industry-level productivity heterogeneity $k^{-1}$ and the difference between EPPs in the bottom and top deciles of $k^{-1}$ is always highly statistically significant. Empirical evidence thus unequivocally supports Corollary 1.

Second, in line with theory we find EPPs and firm size premia to increase with fixed export costs $f_{x}$. Again, as reported in Panel (2) of Table 3, while the magnitude of the size and productivity premium appears to be implausibly high in our naive cross-sectional model, the pattern is in line with Corollary 2. Furthermore, when identifying effects through the withinfirm variation and applying more comprehensive empirical techniques, EPPs decline considerably but still show a similar pattern consistent with theory (see Panel 2 of Table 4). When focusing on the TFP estimates approximating $f_{x}$ with the average size of foreign sales, we find an EPP of $19 \%$ in the industries with the lowest and an EPP of $28 \%$ in industries with the highest $f_{x}$. Furthermore, as indicated by the Wald test the difference between EPP in the bottom and top deciles of fixed export costs is statistically significant irrespective of the underlying estimator and the utilized approximation of $f_{x}$. Accordingly, we find strong universal support for Corollary 2.

Third, we consider variable trade costs $\tau$. Starting with the structural estimates of $\tau$, our very simple cross-sectional model suggests that size and productivity premia of exporting do not significantly vary with $\tau$ as indicated by the Wald tests in Table 3. When identifying EPP through the within-firm variation of exporter status in our more comprehensive econometric models, we find some evidence that EPPs are the higher the smaller the variable trade costs are, thus going counter to Corollary 3 (see Panel (3) of Table 4). Such a pattern is however only weakly statistically significant for the maritime transport costs based measure and the structural estimate of $\tau$ and it does not hold across all employed estimation techniques. Furthermore, when approximating $\tau$ by the share of foreign sales of exporters, the pattern reverses. Accordingly, empirical evidence on Corollary 3 is inconclusive. 
Table 4: EPP in \%, with Proxies for $V$

\begin{tabular}{|c|c|c|c|c|c|c|c|}
\hline & Mean & Bottom Decile & Median & Top Decile & $\begin{array}{l}\text { Wald-Test } \\
\text { Top=Bottom }\end{array}$ & Obs. & Firms \\
\hline \multicolumn{8}{|c|}{ Corollary 1} \\
\hline Labour Prod. & $\begin{array}{c}13.67 * * * \\
(1.27)\end{array}$ & $\begin{array}{c}7.28^{* * *} \\
(1.81)\end{array}$ & $\begin{array}{c}11.73 * * * \\
(1.37)\end{array}$ & $\begin{array}{c}22.63 * * * \\
(1.88)\end{array}$ & $\begin{array}{l}\mathrm{F}=31.88 * * * \\
\mathrm{p}=0.000\end{array}$ & 255219 & 40924 \\
\hline TFP & $\begin{array}{c}18.71^{* * *} \\
(1.16)\end{array}$ & $\begin{array}{c}12.80^{* * *} \\
(1.95)\end{array}$ & $\begin{array}{c}16.90^{* * *} \\
(1.32)\end{array}$ & $\begin{array}{l}26.99 * * * \\
(2.01)\end{array}$ & $\begin{array}{l}\mathrm{F}=18.83^{* * *} \\
\mathrm{p}=0.000\end{array}$ & 251034 & 40802 \\
\hline TFP,Diff-in-Diff & $\begin{array}{c}4.19^{* * *} \\
(0.90)\end{array}$ & $\begin{array}{l}-0.05 \\
(1.84)\end{array}$ & $\begin{array}{c}2.90^{* * *} \\
(1.11)\end{array}$ & $\begin{array}{c}10.05 * * * \\
(1.81)\end{array}$ & $\begin{array}{l}\mathrm{F}=9.77^{* * *} \\
\mathrm{p}=0.002\end{array}$ & 204853 & 33912 \\
\hline Olley-Pakes & $\begin{array}{c}17.30^{* * *} \\
(1.59)\end{array}$ & $\begin{array}{c}11.17^{* * * *} \\
(2.42)\end{array}$ & $\begin{array}{c}15.42^{* * *} \\
(1.74)\end{array}$ & $\begin{array}{c}25.91^{* * * *} \\
(2.63)\end{array}$ & $\begin{array}{l}\mathrm{F}=13.77^{* * *} \\
\mathrm{p}=0.0013\end{array}$ & 251034 & 40802 \\
\hline \multicolumn{8}{|c|}{ Corollary 2} \\
\hline Labour Prod. & $\begin{array}{c}14.01^{* * *} \\
(1.28)\end{array}$ & $\begin{array}{c}9.26^{* * *} \\
(2.79)\end{array}$ & $\begin{array}{c}14.32^{* * *} \\
(1.26)\end{array}$ & $\begin{array}{c}19.97^{* * *} \\
(3.14)\end{array}$ & $\begin{array}{l}\mathrm{F}=4.00^{* *} \\
\mathrm{p}=0.048\end{array}$ & 255056 & 40916 \\
\hline TFP & $\begin{array}{c}18.81^{* * *} \\
(0.99)\end{array}$ & $\begin{array}{c}11.74^{* * *} \\
(1.95)\end{array}$ & $\begin{array}{l}19.27^{* * *} \\
(1.00)\end{array}$ & $\begin{array}{l}27.83^{* * *} \\
(2.67)\end{array}$ & $\begin{array}{l}\mathrm{F}=14.89 * * * \\
\mathrm{p}=0.000\end{array}$ & 250876 & 40793 \\
\hline TFP, Diff-in-Diff & $\begin{array}{c}4.29 * * * \\
(0.71)\end{array}$ & $\begin{array}{l}2.08^{* *} \\
(0.95)\end{array}$ & $\begin{array}{c}4.43^{* * *} \\
(0.72)\end{array}$ & $\begin{array}{c}7.00^{* * *} \\
(1.37)\end{array}$ & $\begin{array}{l}\mathrm{F}=7.17^{* * *} \\
\mathrm{p}=0.009\end{array}$ & 204700 & 33903 \\
\hline Olley-Pakes & $\begin{array}{c}17.53^{* * *} \\
(1.05)\end{array}$ & $\begin{array}{c}11.26^{* * * *} \\
(2.57)\end{array}$ & $\begin{array}{c}17.94^{* * *} \\
(1.09)\end{array}$ & $\begin{array}{c}25.47^{* * * *} \\
(3.69)\end{array}$ & $\begin{array}{l}\mathrm{F}=5.83^{* *} \\
\mathrm{p}=0.025\end{array}$ & 250876 & 40793 \\
\hline \multicolumn{8}{|c|}{ ii: $\mathrm{V} \equiv$ Log average number of export destinations } \\
\hline Labour Prod. & $\begin{array}{c}13.76^{* * *} \\
(1.27)\end{array}$ & $\begin{array}{l}7.78^{* * *} \\
(2.54)\end{array}$ & $\begin{array}{c}14.44^{* * *} \\
(1.26)\end{array}$ & $\begin{array}{c}19.33^{* * *} \\
(2.21)\end{array}$ & $\begin{array}{l}\mathrm{F}=8.24^{* * *} \\
\mathrm{p}=0.005\end{array}$ & 255097 & 40919 \\
\hline TFP & $\begin{array}{l}18.52^{* * *} \\
(1.02)\end{array}$ & $\begin{array}{c}9.53^{* * *} \\
(1.71)\end{array}$ & $\begin{array}{l}19.53^{* * *} \\
(1.02)\end{array}$ & $\begin{array}{l}26.88^{* * *} \\
(1.59)\end{array}$ & $\begin{array}{l}\mathrm{F}=44.59 * * * \\
\mathrm{p}=0.000\end{array}$ & 250912 & 40796 \\
\hline TFP, Diff-in-Diff & $\begin{array}{c}4.41^{* * *} \\
(0.71)\end{array}$ & $\begin{array}{c}3.12^{* * *} \\
(0.85)\end{array}$ & $\begin{array}{c}4.56^{* * *} \\
(0.75)\end{array}$ & $\begin{array}{c}5.55^{* * *} \\
(1.14)\end{array}$ & $\begin{array}{l}\mathrm{F}=2.87^{*} \\
\mathrm{p}=0.094\end{array}$ & 204721 & 33905 \\
\hline Olley-Pakes & $\begin{array}{c}17.22^{* * *} \\
(1.09)\end{array}$ & $\begin{array}{c}9.02^{* * *} \\
(1.62)\end{array}$ & $\begin{array}{c}18.14^{* * *} \\
(1.12)\end{array}$ & $\begin{array}{c}24.81^{* * *} \\
(1.90)\end{array}$ & $\begin{array}{l}\mathrm{F}=32.14^{* * *} \\
\mathrm{p}=0.000\end{array}$ & 250912 & 40796 \\
\hline \multicolumn{8}{|c|}{ iii: $V \equiv \log$ structural estimate of fixed export costs $f_{j t, x}$} \\
\hline Labour Prod. & $\begin{array}{c}14.18 * * * \\
(1.37)\end{array}$ & $\begin{array}{c}9.25 * * * \\
(2.10)\end{array}$ & $\begin{array}{c}14.25 * * * \\
(1.37)\end{array}$ & $\begin{array}{c}18.77 * * * \\
(1.74)\end{array}$ & $\begin{array}{l}\mathrm{F}=12.34 * * * \\
\mathrm{p}=0.001\end{array}$ & 239551 & 40480 \\
\hline TFP & $\begin{array}{c}19.09^{* * *} \\
(1.10)\end{array}$ & $\begin{array}{c}14.42^{* * *} \\
(1.72)\end{array}$ & $\begin{array}{c}19.16^{* * *} \\
(1.10)\end{array}$ & $\begin{array}{c}23.42^{* * *} \\
(1.56)\end{array}$ & $\begin{array}{l}\mathrm{F}=13.61^{* * *} \\
\mathrm{p}=0.000\end{array}$ & 235447 & 40357 \\
\hline TFP, Diff-in-Diff & $\begin{array}{c}4.45^{* * *} \\
(0.81)\end{array}$ & $\begin{array}{c}2.19 \\
(1.35)\end{array}$ & $\begin{array}{c}4.49^{* * *} \\
(0.80)\end{array}$ & $\begin{array}{c}6.52^{* * *} \\
(1.01)\end{array}$ & $\begin{array}{l}\mathrm{F}=6.23^{* *} \\
\mathrm{p}=0.014\end{array}$ & 183522 & 32570 \\
\hline Olley-Pakes & $\begin{array}{c}17.77 * * * \\
(1.28)\end{array}$ & $\begin{array}{c}13.14^{* * *} \\
(2.19)\end{array}$ & $\begin{array}{c}17.84 * * * \\
(1.28)\end{array}$ & $\begin{array}{c}22.06^{* * * *} \\
(1.98)\end{array}$ & $\begin{array}{l}\mathrm{F}=7.36^{* * *} \\
\mathrm{p}=0.013\end{array}$ & 235447 & 40357 \\
\hline
\end{tabular}

Notes: ${ }^{*},{ }^{*},{ }^{* * *}$ statistically significant at the $10 \%$, the $5 \%$, the $1 \%$ levels, respectively. All underlying models control for time-constant (some for time-changing) unobserved firm heterogeneity and time-specific common shocks. 
Table 4: ...continued

\begin{tabular}{|c|c|c|c|c|c|c|c|}
\hline & Mean & Bottom Decile & Median & Top Decile & $\begin{array}{l}\text { Wald-Test } \\
\text { Top=Bottom }\end{array}$ & Obs. & Firms \\
\hline \multicolumn{8}{|c|}{$\begin{array}{r}\text { Corollary } 3 \\
\text { f foreign sales }\end{array}$} \\
\hline Labour Prod. & $\begin{array}{c}14.19^{* * *} \\
(1.17)\end{array}$ & $\begin{array}{c}11.79^{* * *} \\
(1.44)\end{array}$ & $\begin{array}{c}14.16 * * * \\
(1.17)\end{array}$ & $\begin{array}{c}16.46 * * * \\
(1.63)\end{array}$ & $\begin{array}{l}\mathrm{F}=5.38 * * \\
\mathrm{p}=0.022\end{array}$ & 255056 & 40916 \\
\hline TFP & $\begin{array}{c}19.13^{* * *} \\
(0.98)\end{array}$ & $\begin{array}{c}16.30^{* * *} \\
(1.53)\end{array}$ & $\begin{array}{c}19.09^{* * *} \\
(0.98)\end{array}$ & $\begin{array}{c}21.74^{* * *} \\
(1.52)\end{array}$ & $\begin{array}{l}\mathrm{F}=5.40^{* *} \\
\mathrm{p}=0.022\end{array}$ & 250876 & 40793 \\
\hline TFP, Diff-in-Diff & $\begin{array}{c}4.37 * * * \\
(0.75)\end{array}$ & $\begin{array}{c}4.20^{* * * *} \\
(0.81)\end{array}$ & $\begin{array}{c}4.36^{* * *} \\
(0.75)\end{array}$ & $\begin{array}{c}4.51^{* * *} \\
(0.98)\end{array}$ & $\begin{array}{l}\mathrm{F}=0.10 \\
\mathrm{p}=0.756\end{array}$ & 204700 & 33903 \\
\hline Olley-Pakes & $\begin{array}{c}17.78^{* * *} \\
(1.11)\end{array}$ & $\begin{array}{c}14.98^{* * * *} \\
(1.57)\end{array}$ & $\begin{array}{c}17.74^{* * * *} \\
(1.10)\end{array}$ & $\begin{array}{c}20.38^{* * *} \\
(2.05)\end{array}$ & $\begin{array}{l}\mathrm{F}=3.43^{*} \\
\mathrm{p}=0.078\end{array}$ & 250876 & 40793 \\
\hline \multicolumn{8}{|c|}{ ii:V $\equiv$ Gravity model absolute size of distance parameter } \\
\hline Labour Prod. & $\begin{array}{c}14.24^{* * *} \\
(1.35)\end{array}$ & $\begin{array}{l}15.94^{* * *} \\
(1.91)\end{array}$ & $\begin{array}{c}14.60^{* * * *} \\
(1.19)\end{array}$ & $\begin{array}{c}12.03^{* * *} \\
(3.66)\end{array}$ & $\begin{array}{l}\mathrm{F}=0.62 \\
\mathrm{p}=0.435\end{array}$ & 231498 & 36963 \\
\hline TFP & $\begin{array}{c}18.94^{* * * *} \\
(1.26)\end{array}$ & $\begin{array}{c}20.65^{* * *} \\
(1.39)\end{array}$ & $\begin{array}{c}19.30 * * * \\
(0.99)\end{array}$ & $\begin{array}{c}16.73^{* * *} \\
(3.58)\end{array}$ & $\begin{array}{l}\mathrm{F}=0.74 \\
\mathrm{p}=0.393\end{array}$ & 227583 & 36844 \\
\hline TFP, Diff-in-Diff & $\begin{array}{c}4.40^{* * * *} \\
(0.76)\end{array}$ & $\begin{array}{c}5.22^{* * *} \\
(1.12)\end{array}$ & $\begin{array}{c}4.57^{* * *} \\
(0.75)\end{array}$ & $\begin{array}{l}3.32^{* *} \\
(1.53)\end{array}$ & $\begin{array}{l}\mathrm{F}=0.77 \\
\mathrm{p}=0.383\end{array}$ & 185647 & 30571 \\
\hline Olley-Pakes & $\begin{array}{c}17.72^{* * *} \\
(1.53)\end{array}$ & $\begin{array}{c}18.95 * * * \\
(1.62)\end{array}$ & $\begin{array}{c}17.98^{* * *} \\
(1.25)\end{array}$ & $\begin{array}{c}16.13^{* * *} \\
(4.13)\end{array}$ & $\begin{array}{l}F=0.30 \\
p=0.591\end{array}$ & 227583 & 36844 \\
\hline \multicolumn{8}{|c|}{ 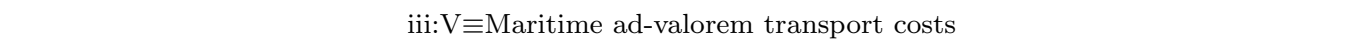 } \\
\hline Labour Prod. & $\begin{array}{c}14.63^{* * *} \\
(1.28)\end{array}$ & $\begin{array}{c}16.15^{* * * *} \\
(1.52)\end{array}$ & $\begin{array}{c}15.10^{* * * *} \\
(1.32)\end{array}$ & $\begin{array}{l}11.82^{* * * *} \\
(1.72)\end{array}$ & $\begin{array}{l}\mathrm{F}=4.73^{* *} \\
\mathrm{p}=0.032\end{array}$ & 251722 & 40680 \\
\hline TFP & $\begin{array}{c}19.41^{* * *} \\
(1.25)\end{array}$ & $\begin{array}{c}20.46^{* * *} \\
(1.48)\end{array}$ & $\begin{array}{c}19.73^{* * *} \\
(1.28)\end{array}$ & $\begin{array}{c}17.39 * * * \\
(1.78)\end{array}$ & $\begin{array}{l}\mathrm{F}=2.24 \\
\mathrm{p}=0.138\end{array}$ & 247575 & 40551 \\
\hline TFP, Diff-in-Diff & $\begin{array}{c}4.41^{* * *} \\
(0.79)\end{array}$ & $\begin{array}{c}4.65^{* * * *} \\
(0.95)\end{array}$ & $\begin{array}{c}4.48^{* * *} \\
(0.80)\end{array}$ & $\begin{array}{c}3.95^{* * *} \\
(1.40)\end{array}$ & $\begin{array}{l}\mathrm{F}=0.17 \\
\mathrm{p}=0.680\end{array}$ & 201067 & 33517 \\
\hline Olley-Pakes & $\begin{array}{c}18.13^{* * *} \\
(1.40)\end{array}$ & $\begin{array}{c}19.35 * * * \\
(1.52)\end{array}$ & $\begin{array}{c}18.50^{* * *} \\
(1.41)\end{array}$ & $\begin{array}{c}15.82^{* * *} \\
(1.80)\end{array}$ & $\begin{array}{l}\mathrm{F}=4.28^{*} \\
\mathrm{p}=0.051\end{array}$ & 247575 & 40551 \\
\hline \multicolumn{8}{|c|}{ iv: $\mathrm{V} \equiv$ Log structural estimate of iceberg costs $\tau_{j t}$} \\
\hline Labour Prod. & $\begin{array}{c}13.98^{* * *} \\
(1.30)\end{array}$ & $\begin{array}{c}16.50^{* * * *} \\
(1.74)\end{array}$ & $\begin{array}{c}14.29 * * * \\
(1.29)\end{array}$ & $\begin{array}{c}10.78^{* * * *} \\
(2.25)\end{array}$ & $\begin{array}{l}\mathrm{F}=3.57^{*} \\
\mathrm{p}=0.062\end{array}$ & 236263 & 40262 \\
\hline TFP & $\begin{array}{c}19.12^{* * * *} \\
(1.09)\end{array}$ & $\begin{array}{c}21.53^{* * *} \\
(1.54)\end{array}$ & $\begin{array}{c}19.42^{* * *} \\
(1.06)\end{array}$ & $\begin{array}{c}16.04^{* * * *} \\
(2.25)\end{array}$ & $\begin{array}{l}\mathrm{F}=3.12^{*} \\
\mathrm{p}=0.080\end{array}$ & 232224 & 40142 \\
\hline TFP, Diff-in-Diff & $\begin{array}{c}4.53^{* * *} \\
(0.77)\end{array}$ & $\begin{array}{c}5.38^{* * * *} \\
(0.88)\end{array}$ & $\begin{array}{c}4.63^{* * *} \\
(0.77)\end{array}$ & $\begin{array}{c}3.43^{* * * *} \\
(1.01)\end{array}$ & $\begin{array}{l}\mathrm{F}=3.38^{*} \\
\mathrm{p}=0.069\end{array}$ & 180165 & 32267 \\
\hline Olley-Pakes & $\begin{array}{c}17.72^{* * *} \\
(1.29)\end{array}$ & $\begin{array}{c}20.19 * * * \\
(1.72)\end{array}$ & $\begin{array}{c}18.02^{* * *} \\
(1.25)\end{array}$ & $\begin{array}{c}14.55^{* * *} \\
(2.61)\end{array}$ & $\begin{array}{l}\mathrm{F}=2.61 \\
\mathrm{p}=0.121\end{array}$ & 232224 & 40142 \\
\hline
\end{tabular}

Notes: $*, * *, * * *$ statistically significant at the $10 \%$, the $5 \%$, the $1 \%$ levels, respectively. All underlying models control for time-constant (some for time-changing) unobserved firm heterogeneity and time-specific common shocks. 
Table 4: ...continued

\begin{tabular}{|c|c|c|c|c|c|c|c|}
\hline & Mean & Bottom Decile & Median & Top Decile & $\begin{array}{l}\text { Wald-Test } \\
\text { Top=Bottom }\end{array}$ & Obs. & Firms \\
\hline \multicolumn{8}{|c|}{ Corollary 4} \\
\hline \multicolumn{8}{|c|}{$\mathrm{i}: \mathrm{V} \equiv$ Capital intensity of domestic firms } \\
\hline Labour Prod. & $\begin{array}{c}14.15 * * * \\
(1.34)\end{array}$ & $\begin{array}{c}13.39 * * * \\
(1.63)\end{array}$ & $\begin{array}{c}13.88 * * * \\
(1.43)\end{array}$ & $\begin{array}{c}15.30 * * * \\
(1.33)\end{array}$ & $\begin{array}{l}\mathrm{F}=1.73 \\
\mathrm{p}=0.191\end{array}$ & 255142 & 40923 \\
\hline TFP & $\begin{array}{c}18.65^{* * *} \\
(1.24)\end{array}$ & $\begin{array}{c}15.55^{* * * *} \\
(1.51)\end{array}$ & $\begin{array}{c}17.51^{* * *} \\
(1.31)\end{array}$ & $\begin{array}{c}23.47^{* * *} \\
(1.44)\end{array}$ & $\begin{array}{l}\mathrm{F}=22.38^{* * *} \\
\mathrm{p}=0.000\end{array}$ & 250958 & 40800 \\
\hline TFP, Diff-in-Diff & $\begin{array}{c}4.24^{* * *} \\
(0.76)\end{array}$ & $\begin{array}{l}3.25^{* * *} \\
(0.91)\end{array}$ & $\begin{array}{c}3.88^{* * *} \\
(0.79)\end{array}$ & $\begin{array}{c}5.75^{* * *} \\
(1.02)\end{array}$ & $\begin{array}{l}\mathrm{F}=4.51^{* *} \\
\mathrm{p}=0.036\end{array}$ & 204759 & 33905 \\
\hline Olley-Pakes & $\begin{array}{c}17.35^{* * * *} \\
(1.40)\end{array}$ & $\begin{array}{c}14.63^{* * *} \\
(1.72)\end{array}$ & $\begin{array}{c}16.35^{* * *} \\
(1.48)\end{array}$ & $\begin{array}{c}21.55^{* * *} \\
(1.71)\end{array}$ & $\begin{array}{l}\mathrm{F}=11.52^{* * *} \\
\mathrm{p}=0.003\end{array}$ & 250958 & 40800 \\
\hline \multicolumn{8}{|c|}{ ii: $\mathrm{V} \equiv$ Log average size of domestic sales } \\
\hline Labour Prod. & $\begin{array}{c}14.24^{* * * *} \\
(1.40)\end{array}$ & $\begin{array}{c}13.53^{* * * *} \\
(2.66)\end{array}$ & $\begin{array}{c}14.25^{* * *} \\
(1.38)\end{array}$ & $\begin{array}{c}14.87^{* * * *} \\
(1.53)\end{array}$ & $\begin{array}{l}\mathrm{F}=0.17 \\
\mathrm{p}=0.682\end{array}$ & 255211 & 40924 \\
\hline TFP & $\begin{array}{c}19.06 * * * \\
(1.27)\end{array}$ & $\begin{array}{c}16.90^{* * *} \\
(2.32)\end{array}$ & $\begin{array}{l}19.11^{* * *} \\
(1.26)\end{array}$ & $\begin{array}{c}21.03^{* * * *} \\
(1.37)\end{array}$ & $\begin{array}{l}\mathrm{F}=2.18 \\
\mathrm{P}=0.143\end{array}$ & 251026 & 40802 \\
\hline TFP, Diff-in-Diff & $\begin{array}{c}4.29 * * * \\
(0.79)\end{array}$ & $\begin{array}{c}3.49 * * * \\
(1.21)\end{array}$ & $\begin{array}{c}4.31^{* * *} \\
(0.78)\end{array}$ & $\begin{array}{c}5.03^{* * * *} \\
(0.96)\end{array}$ & $\begin{array}{l}F=1.05 \\
p=0.309\end{array}$ & 204840 & 33911 \\
\hline Olley-Pakes & $\begin{array}{c}17.75^{* * *} \\
(1.49)\end{array}$ & $\begin{array}{c}16.18^{* * *} \\
(2.64)\end{array}$ & $\begin{array}{c}17.79 * * * \\
(1.47)\end{array}$ & $\begin{array}{c}19.17^{* * * *} \\
(1.44)\end{array}$ & $\begin{array}{l}\mathrm{F}=1.01 \\
\mathrm{p}=0.327\end{array}$ & 251026 & 40802 \\
\hline \multicolumn{8}{|c|}{ iii: $\mathrm{V} \equiv \log$ structural estimate of fixed production costs $f_{j t}$} \\
\hline Labour Prod. & $\begin{array}{c}13.81 * * * \\
(1.50)\end{array}$ & $\begin{array}{c}8.26 * * * \\
(2.47)\end{array}$ & $\begin{array}{c}13.86 * * * \\
(1.50)\end{array}$ & $\begin{array}{c}19.28 * * * \\
(1.75)\end{array}$ & $\begin{array}{l}\mathrm{F}=12.81 * * * \\
\mathrm{p}=0.001\end{array}$ & 240302 & 40570 \\
\hline TFP & $\begin{array}{c}18.78^{* * *} \\
(1.22)\end{array}$ & $\begin{array}{c}13.52^{* * *} \\
(1.91)\end{array}$ & $\begin{array}{c}18.82^{* * *} \\
(1.22)\end{array}$ & $\begin{array}{c}23.95^{* * * *} \\
(1.64)\end{array}$ & $\begin{array}{l}\mathrm{F}=16.28^{* * *} \\
\mathrm{p}=0.000\end{array}$ & 236175 & 40448 \\
\hline TFP, Diff-in-Diff & $\begin{array}{c}4.28^{* * *} \\
(0.91)\end{array}$ & $\begin{array}{l}1.73 \\
(1.52)\end{array}$ & $\begin{array}{c}4.30^{* * *} \\
(0.90)\end{array}$ & $\begin{array}{c}6.74^{* * *} \\
(1.00)\end{array}$ & $\begin{array}{l}\mathrm{F}=7.62^{* * *} \\
\mathrm{p}=0.007\end{array}$ & 184239 & 32645 \\
\hline Olley-Pakes & $\begin{array}{c}17.45 * * * \\
(1.41)\end{array}$ & $\begin{array}{c}12.26 \text { *** } \\
(2.32)\end{array}$ & $\begin{array}{c}17.50^{* * *} \\
(1.41)\end{array}$ & $\begin{array}{c}22.56 \text { *** } \\
(2.12)\end{array}$ & $\begin{array}{l}\mathrm{F}=8.96 * * * \\
\mathrm{p}=0.007\end{array}$ & 236175 & 40448 \\
\hline \multicolumn{8}{|c|}{ Corollary 5} \\
\hline Labour Prod. & $\begin{array}{c}13.43 * * * \\
(1.28)\end{array}$ & $\begin{array}{c}23.05 * * * \\
(2.14)\end{array}$ & $\begin{array}{c}12.22 * * * \\
(1.35)\end{array}$ & $\begin{array}{c}5.91 * * * \\
(2.14)\end{array}$ & $\begin{array}{l}\mathrm{F}=24.23^{* * *} \\
\mathrm{p}=0.000\end{array}$ & 255219 & 40924 \\
\hline TFP & $\begin{array}{c}18.44^{* * *} \\
(1.18)\end{array}$ & $\begin{array}{c}27.78^{* * * *} \\
(2.04)\end{array}$ & $\begin{array}{c}17.25^{* * *} \\
(1.31)\end{array}$ & $\begin{array}{c}11.05^{* * *} * \\
(2.36)\end{array}$ & $\begin{array}{l}\mathrm{F}=19.03^{* * *} \\
\mathrm{p}=0.000\end{array}$ & 251034 & 40802 \\
\hline TFP, Diff-in-Diff & $\begin{array}{c}4.00^{* * * *} \\
(0.93)\end{array}$ & $\begin{array}{c}10.07^{* * *} * \\
(1.90)\end{array}$ & $\begin{array}{c}3.23^{* * *} \\
(1.06)\end{array}$ & $\begin{array}{l}-0.88 \\
(2.15)\end{array}$ & $\begin{array}{l}\mathrm{F}=8.85^{* * *} \\
\mathrm{p}=0.004\end{array}$ & 204853 & 33912 \\
\hline Olley-Pakes & $\begin{array}{c}17.04^{* * *} \\
(1.52)\end{array}$ & $\begin{array}{c}26.56^{* * *} \\
(2.45)\end{array}$ & $\begin{array}{c}15.83^{* * *} \\
(1.68)\end{array}$ & $\begin{array}{c}9.52^{* * *} \\
(2.92)\end{array}$ & $\begin{array}{l}\mathrm{F}=13.70^{* * *} \\
\mathrm{p}=0.001\end{array}$ & 251034 & 40802 \\
\hline
\end{tabular}

Notes: *, $* *, * * *$ statistically significant at the $10 \%$, the $5 \%$, the $1 \%$ levels, respectively. All underlying models control for time-constant (some for time-changing) unobserved firm heterogeneity and time-specific common shocks. 
Fourth, we analyse EPPs in relation to industries' fixed costs of production. Contrary to Corollary 4, Panel (4) of Table 3 shows that the EPP and the exporter size premium strongly increase in our structural estimate of fixed production costs $f$. This pattern persists and remains statistically significant when switching to the more elaborate econometric models controlling for unobserved firm and time characteristics. Focusing on the standard TFP specification, we find the average EPP in the bottom decile of the structural estimate of $f$ to be $14 \%$ while the average EPP in the top decile of $f$ is $24 \%$. As indicated by the Wald test, EPP differences between the bottom and top deciles of the structural estimate of $f$ are highly statistically significant, irrespective of the underlying estimation technique. However, it should be noted that $f$ and $f_{x}$ are highly positively correlated (which also prevents their simultaneous inclusion in the model) casting some doubt on whether the observed pattern in EPPs indeed is related to fixed production costs or rather to fixed export costs. We address this issue by turning to our non-structural proxies for the fixed costs of production. From Panel (4) of Table 4 it follows that the picture on the differences in EPP between the top and bottom deciles is less clear. For the capital-intensity proxy the difference remains significant for three of the four estimation techniques, and for the average-domestic-sales proxy the difference always is statistically insignificant. Accordingly, empirical evidence on Corollary 4 is mixed.

Fifth, we regard EPPs subject to industry-specific structural estimates of the elasticity of substitution. While Corollary 5 had an ambiguous prediction, the data displays some strong patterns for the elasticity of substitution in a sector irrespective of the applied estimation technique. The naive crosssectional model reported in Panel (5) of Table 3 indicates that sectors with lower elasticity of substitution command higher EPPs and higher size premia. Put differently, the further away a sector is from the perfect competition benchmark, the larger is the EPP. This result also holds after controlling for unobserved firm- and time-specific heterogeneity in our more comprehensive econometric models reported in Panel (5) of Table 4. For instance, when focusing on our TFP estimates, export activities in industries in the top decile of $\sigma$ are associated with an EPP of only 11\% while the EPP in the bottom decile of $\sigma$ is $28 \% .^{25}$

\footnotetext{
${ }^{25}$ This role of the intra-sectoral elasticity of substitution raises the question if other industry structure measures could be underlying drivers of the EPP. We have accordingly checked the most common measure, namely the Herfindahl industry concentration measure. The Herfindahl index in the theoretical model is given by $H_{j}=$ $\frac{1}{M_{j}}\left(1+\frac{\left(\sigma_{j}-1\right)^{2}}{k_{j}\left(k_{j}-2\left(\sigma_{j}-1\right)\right)}\right)$, where $M_{j}$ is the mass of domestic firms. Thus, the theoretical equivalent of the Herfindahl index has an ambiguous relation to the EPP in (8). Similarly, our empirical tests found no response of the EPP to sectoral industry concentration.
} 


\subsection{Conclusions for Empirical Research}

It is worth to explicitly state that the essential issue in the paper is not to show how to avoid bias when estimating EPPs. Industry-specific and for that matter country-specific EPPs can be estimated without conditioning on industry- or country-specific characteristics, respectively. One could even argue that including controls for all industry-specific characteristics (e.g., by including industry-time-specific constants) would result in an over-specified model understating the true EPP that according to our theory exactly depends on some of these characteristics. However, the important issue is that our results show that when it comes to solving the puzzle of why EPPs differ so widely between industries and countries, one has to take into account the different industry-characteristics derived from the theory and corresponding industry-structures of countries. As such, our paper has identified several relevant parameters that drive the magnitude of observed EPP, the central candidates being fixed costs of exporting, the intra-sectoral elasticity of substitution and not least the industry-level productivity heterogeneity. Obviously, this in turn implies that the origins for sector (or country) differences in these characteristics are important future alleys for empirical research. In particular, on the persistence of productive differences Syverson (2011) draws up an comprehensive overview of existing results and directions for future research.

In order to demonstrate how much of the cross-industry variation in EPPs, that we see in the data, can be explained by the different industry characteristics that we have identified, we first estimate EPPs based on simple labour productivity as well as TFP regressions controlling for unobserved firm- and time-specific heterogeneity for the years 1995 to 2007 separately for all 99 3-digit industries. In a next step we regress the so obtained 99 EPPs on the respective industry characteristics starting with the standard deviation of log productivity, our measure for productivity dispersion $k_{j t}^{-1}$ in Corollary 1. The transformed residuals of these regressions can be interpreted as conditional EPPs, i.e. they reflect the part of EPPs that is not explained by industry characteristics. Table 5 depicts the standard deviation as well as minimum and maximum values of average industry-level EPPs, unconditional as well as conditional. Based on labour productivity regressions the standard deviation of EPPs drops from 8.7 percentage points to 7.6 percentage points after controlling for $k_{j t}^{-1}$ and further to 7.2 percentage points after also controlling for $f_{j t, x}, \tau_{j t}, f_{j t}$, and $\sigma_{j t}$. For the TFP based EPPs their standard deviation drops from 11.4 percentage points to 8.7 percentage points when controlling for $k_{j t}^{-1}$ and falls further when controlling for the other industry characteristics. Thus, by simply taking into account 
industry-level productivity dispersion $\left(k_{j t}^{-1}\right)$, a measure that in principle is available to each and every researcher working with firm-level data, one can already explain up to $31 \%$ of the observed size differences of EPPs.

\section{Table 5: Explaining EPP differences}

\begin{tabular}{|c|c|c|c|}
\hline Industry-by-Industry EPP - Labour Productivity & $\mathrm{SD}$ & Min & $\operatorname{Max}$ \\
\hline uncondional & 8.66 & -4.04 & 46.15 \\
\hline conditional on $k_{j t}^{-1}$ & 7.55 & -16.48 & 27.71 \\
\hline $\begin{array}{l}\text { conditional on } k_{j t}^{-1} \text { and empirical proxies for } \\
f_{j t, x}, \tau_{j t}, f_{j t}, \sigma_{j t}\end{array}$ & 7.23 & -19.33 & 26.86 \\
\hline Industry-by-Industryl EPP - TFP & $\mathrm{SD}$ & Min & $\operatorname{Max}$ \\
\hline uncondional & 11.41 & 4.08 & 71.03 \\
\hline conditional on $k_{j t}^{-1}$ & 8.67 & -24.73 & 34.86 \\
\hline $\begin{array}{l}\text { conditional on } k_{j t}^{-1} \text { and empirical proxies for } \\
f_{j t, x}, \tau_{j t}, f_{j t}, \sigma_{j t}\end{array}$ & 8.34 & -22.73 & 35.72 \\
\hline
\end{tabular}

\section{Summary}

Exporter productivity premia are a central stylised fact of international economics, albeit the accumulated empirical evidence discloses substantial and so far unexplained - EPP size differences between countries and across sectors within countries. The present paper tackles this issue both theoretically and empirically. First, we ask if at all - and in what direction - the workhorse model of heterogeneous firms trade (e.g. Melitz, 2003) contains predictions on the determinants of magnitude for exporter productivity premia. In particular, we introduce an explicit EPP measure into a version of the Melitz (2003) model. Second, we compare the theoretical predications to the evidence derived from Danish firm-level data, by estimating a range of empirical models commonly found in the literature. We are able to identify an important role for fixed trade costs and for the degree of heterogeneity in productivity in explaining the variance in EPP magnitude. Both theoretically and empirically, industries where the realised productivity distribution displays a wider variance feature larger EPPs; similarly, industries with higher fixed trade costs display larger EPPs. Moreover, while in theory 
the intra-sectoral elasticity of substitution (and hence the degree of product differentiation) has ambiguous effects on EPP magnitude, we find strong empirical patterns that sectors with lower elasticity of substitution command larger EPPs.

Our results contribute several directions for future research. In terms of theoretical extensions, for example, the relation between the elasticity of substitution and the EPP found in the data should ideally, if confirmed by other empirical studies, feature in the models of international trade. Similarly, the theoretical and empirical link between fixed export costs (which matter in the policy debate surrounding trade facilitation) and observable EPP could be further investigated. Most importantly, our findings put new perspective on the sizable empirical literature on exporter productivity premia. We highlight two directions in which the present paper contributes. Firstly, we are able to identify some central fundamentals that matter - and are robust to the various specifications tested. We establish that the variance in the underlying productivity distribution, the size of fixed export costs, and the intra-sectoral elasticity of substitution are decisive fundamentals for EPP realisations. These findings, if supported by other empirical studies, are worthy candidates for future stylised facts. Secondly, our analysis suggests that the cross-country variation in EPPs observed in the literature can at least partly be explained by cross-country differences in industry structure and industry characteristics. Namely, that estimates of the EPP may differ across industries and countries due to measurable variations in productivity dispersion, fixed export costs, and market power reflected in the elasticity of substitution. 


\section{References}

Ackerberg, D.A., K. Caves, and G. Frazer (2006) 'Structural Identification of Production Functions,' MPRA Paper 38349.

Aw, B.Y., S. Chung, and M.J. Roberts (2000) 'Productivity and Turnover in the Export Market: Micro-level Evidence from the Republic of Korea and Taiwan (China),' The World Bank Economic Review 14, 65-90.

Aw, B. Y., and A. R. Hwang (1995) 'Productivity and the Export Market: A Firm-level Analysis,' Journal of Development Economics 47, 313-332.

Axtell, R.L. (2001) 'Zipf Distribution of U. S. Firm Sizes, ' Science 293(5536), 1818-1820.

Bernard, A.B., J. B.Jensen, S.J. Redding, and P.K. Schott (2007) 'Firms in International Trade,' Journal of Economic Perspectives 21 (3), 105-130.

Bernard, A.B., J.B. Jensen, S.J. Redding, and P.K. Schott (2012) 'The Empirics of Firm Heterogeneity and International Trade,' Annual Review of Economics 4, 283-313.

Bernard, A.B., J. Eaton, J.B. Jensen, and S. Kortum (2003) 'Plants and Productivity in International Trade,' American Economic Review 93, 1268-1290.

Bustos, P. (2011) 'Trade Liberalization, Exports, and Technology Upgrading: Evidence on the Impact of MERCOSUR on Argentinian Firms,' American Economic Review, 101(1), 304-340.

Chaney, T. (2008) 'Distorted Gravity: Heterogeneous Firms, Market Structure, and the Geography of International Trade,' American Economic Review 98, 1707-1721.

De Loecker, J. (2007) 'Do exports generate higher productivity? Evidence from Slovenia,' Journal of International Economics 73(1), 69-98.

Dixit, A.K., and J.E. Stiglitz (1977) 'Monopolistic Competition and Optimum Product Diversity, ' American Economic Review 67(3), 297-308.

Eaton, J., S.S. Kortum, and S. Sotelo (2012) 'International Trade: Linking Micro and Macro,', NBER Working Paper 17864.

Farinas, J. C., and A. Martin-Marcos (2007) 'Exporting and Economic Performance: Firm-level Evidence of Spanish Manufacturing', World Economy 30, 618-646.

Greenaway, D., and R. Kneller (2007) 'Firm Heterogeneity, Exporting and Foreign Direct Investment,' The Economic Journal 117, 134-161.

Head, K., and J. Ries, (2003) 'Heterogeneity and the foreign direct investment versus exporter decision of Japanese manufacturers,' Journal of the Japanese and International Economics 17, 448-467.

Head K., T. Mayer, and J. Ries (2010) 'The erosion of colonial trade linkages 
after independence,' Journal of International Economics 81, 1-14.

Helpman, E., M.J. Melitz, and S.R. Yeaple (2004) 'Export versus FDI with

Heterogeneous Firms,' American Economic Review 94, 300-316.

ISGEP - International Study Group on Exports and Productivity (2008) 'Understanding cross-country differences in export premia: Comparable evidence for 14 countries, Review of World Economics 144, 596-635.

Kneller, R., and M. Pisu (2010) 'The returns to exporting: evidence from UK Firms,' Canadian Journal of Economics 43 (2), 494-519.

López, R.A. (2009) 'Do Firms Increase Productivity in Order to Become Exporters?', Oxford Bulletin of Economics and Statistics 71 (5), 621642.

Luttmer, E.G. (2007) 'Selection, Growth , and the size distribution of firms,' Quarterly Journal of Economics 122 (3), 1103-1144.

Máñez, J.A., M.E. Rochina-Barrachina, and J.A. Sanchis (2008) 'Sunk Costs Hysteresis in Spanish Manufacturing Exports,' Review of World Economics, 144(2), 272-294.

Marin, A.G., and N. Voigtländer (2013) 'Exporting and plant-level efficiency gains: It's in the measure,' NBER Working Paper 19033.

Melitz, M.J. (2003) 'The Impact of Trade on Intra-industry Reallocations and Aggregate Industry Productivity,' Econometrica 71, 1695-1725.

Merino, F. (2004) 'Firms' productivity and internationalization: a statistical dominance test,' Applied Economics Letters 11, 851-854.

Olley, S., and A. Pakes (1996) 'The dynamics of productivity in the telecommunications equipment industry,' Econometrica 64 (6), 1263-1298.

Redding, S. J. (2011) 'Theories of Heterogeneous Firms and Trade,' Annual Review of Economics 3, 77-105.

Schröder, P.J.H., and A. Sørensen (2012) 'Second Thoughts on the Exporter Productivity Premium,' Canadian Journal of Economics 45 (4), 13101331.

Silva, J.M.C.S., and S. Tenreyro (2006) 'The Log of Gravity', Review of Economics and Statistics, 88, 641-658.

Simon, H.A., and C.P. Bonini (1958) 'The Size Distribution of Business Firms,' American Economic Review 48 (4), 607-617.

Syverson, C. (2004) 'Product Substitutability and Productivity Dispersion,'Review of Economics and Statistics, 86 (2), 534-550.

Syverson, C. (2011) 'What determines Productivity,' Journal of Economic Literature, 49 (2), 326365.

Vinzenzo, V., and J. Wagner (2011) 'Robust Estimation of Linear Fixed Effects Panel Data Models with an Application to the Exporter Pro- 
ductivity Premium,' Jahrbücher f. Nationalökonomie u. Statistik, 231 (4), 546-557.

Wagner, J. (2007) 'Exports and Productivity: A Survey of the Evidence from Firm-level Data,' The World Economy 30, 60-82.

Wagner, J. (2012) 'International trade and firm performance: a survey of empirical studies since 2006,' Review of World Economics 148 (2), 235267. 


\section{Appendix: Robustness Analysis}

We proceed by testing for the robustness of our findings with respect to the definition of an exporting firm. As an alternative we only classify firms as exporters if they export in the current year and in the immediate previous and subsequent years $(t, t-1, t+1)$. Thus, we condition on exporting being a longer-term activity. Naturally, we loose the first and last observations for each firm, which considerably reduces the overall sample size. Table 6 reports the respective findings for our main TFP specification. Overall, EPPs are smaller than the ones reported in Tables 3 and 4 . However, after reestimating our baseline model including the standard exporter definition but the sample from Table 6, thus omitting the first and last observations for each firm, we can confirm that this is driven by the reduced sample size. Furthermore, the patterns with respect to EPP magnitude along the various industry characteristics are very similar to our previous findings for the main TFP specification. Thus, we can confirm our main findings on Corollaries 1 to 5 for the alternative definition considering only longer-term exporters.

\section{Table 6: Long-term EPP in \%, Structural Estimates of $V$}

\begin{tabular}{|c|c|c|c|c|c|c|}
\hline Mean & Bottom Decile & Median & Top Decile & $\begin{array}{l}\text { Wald-Test } \\
\text { Top=Bottom }\end{array}$ & Obs. & Firms \\
\hline \multicolumn{7}{|c|}{ Corollary 1:V $\equiv$ Structural estimate of productivity heterogeneity $k_{j t}^{-1}$} \\
\hline $\begin{array}{c}12.14^{* * *} \\
(1.30)\end{array}$ & $\begin{array}{c}7.52^{* * * *} \\
(2.06)\end{array}$ & $\begin{array}{c}10.68^{* * *} \\
(1.45)\end{array}$ & $\begin{array}{c}18.36^{* * * *} \\
(2.09)\end{array}$ & $\begin{array}{l}\mathrm{F}=10.91^{* * *} \\
\mathrm{p}=0.001\end{array}$ & 162405 & 28859 \\
\hline \multicolumn{7}{|c|}{ Corollary 2: $\mathrm{V} \equiv \log$ structural estimate of fixed export costs $f_{j t, x}$} \\
\hline $\begin{array}{c}12.42^{* * *} \\
(1.31) \\
\end{array}$ & $\begin{array}{c}9.19^{* * *} \\
(1.94)\end{array}$ & $\begin{array}{c}12.52^{* * *} \\
(1.30) \\
\end{array}$ & $\begin{array}{c}15.29 * * * \\
(1.53)\end{array}$ & $\begin{array}{l}\mathrm{F}=7.12^{* * *} \\
\mathrm{p}=0.009\end{array}$ & 162405 & 28859 \\
\hline \multicolumn{7}{|c|}{ Corollary 3:V $\equiv \log$ structural estimate of iceberg costs $\tau_{j t}$} \\
\hline $\begin{array}{c}12.24^{* * *} \\
(1.30)\end{array}$ & $\begin{array}{c}15.82^{* * *} \\
(2.11)\end{array}$ & $\begin{array}{c}12.71^{* * *} \\
(1.23)\end{array}$ & $\begin{array}{c}7.64^{* * *} \\
(3.45)\end{array}$ & $\begin{array}{l}\mathrm{F}=2.71 \\
\mathrm{p}=0.103\end{array}$ & 162405 & 28859 \\
\hline \multicolumn{7}{|c|}{ Corollary 4:V $\equiv$ Log structural estimate of fixed production costs $f_{j t}$} \\
\hline $\begin{array}{c}12.08^{* * *} * \\
(1.32)\end{array}$ & $\begin{array}{c}8.77^{* * * *} \\
(1.85) \\
\end{array}$ & $\begin{array}{c}12.15^{* * *} \\
(1.31)\end{array}$ & $\begin{array}{c}15.50^{* * * *} \\
(1.50)\end{array}$ & $\begin{array}{l}\mathrm{F}=10.18^{* * *} \\
\mathrm{p}=0.002\end{array}$ & 162405 & 28859 \\
\hline \multicolumn{7}{|c|}{ Corollary $\mathbf{5}: \mathrm{V} \equiv$ Structural estimate of elasticity of substitution $\sigma_{j t}$} \\
\hline $\begin{array}{c}12.00^{* * *} \\
(1.24)\end{array}$ & $\begin{array}{c}19.36^{* * *} \\
(1.84)\end{array}$ & $\begin{array}{c}10.75^{* * *} \\
(1.36)\end{array}$ & $\begin{array}{c}5.82^{* * *} \\
(2.13)\end{array}$ & $\begin{array}{l}\mathrm{F}=18.18^{* * *} \\
\mathrm{p}=0.000\end{array}$ & 162405 & 28859 \\
\hline
\end{tabular}

Notes: *,**,*** statistically significant at the $10 \%$, the $5 \%$, the $1 \%$ levels, respectively. All underlying models control for time-constant unobserved firm heterogeneity and time-specific common shocks.

Finally, we test whether our EPP estimates are robust to potential re- 
versed causality, i.e. to the idea that the most productive firms do not select into exporting but become more productive through exporting. To do so we estimate Equation (18) with $\ln T F P_{i t-3}$ as the dependent variable, hence, we quantify EPPs prior to exporting thereby reducing potential simultaneity. This should also take care of any potential simultaneity between our industry-level aggregates $V_{j t}$ and firm-level productivity. The respective EPP estimates are presented in Table 7. Most notably, although EPPs are overall smaller than in our previous regressions, we find patterns very similar to our main contemporaneous TFP specification.

\section{Table 7: EPP in \%, with $\ln T F P_{i t-3}$ and Structural Estimates of $V$}

\begin{tabular}{|c|c|c|c|c|c|c|}
\hline Mean V & Bottom Decile V & Median V & Top Decile V & $\begin{array}{l}\text { Wald-Test } \\
\text { Top=Bottom }\end{array}$ & Obs. & Firms \\
\hline \multicolumn{7}{|c|}{ Corollary $1: \mathrm{V} \equiv$ Structural estimate of productivity heterogeneity $k_{j t}^{-1}$} \\
\hline $\begin{array}{c}4.61^{* * *} \\
(0.77)\end{array}$ & $\begin{array}{c}3.36^{* * *} \\
(0.99)\end{array}$ & $\begin{array}{c}4.21^{* * *} \\
(0.81)\end{array}$ & $\begin{array}{c}6.26^{* * *} \\
(0.97)\end{array}$ & $\begin{array}{l}\mathrm{F}=5.69^{* *} \\
\mathrm{p}=0.019\end{array}$ & 128526 & 25443 \\
\hline \multicolumn{7}{|c|}{ Corollary $2: \mathrm{V} \equiv \log$ structural estimate of fixed export costs $f_{j t, x}$} \\
\hline $\begin{array}{c}4.50^{* * *} \\
(0.72)\end{array}$ & $\begin{array}{l}1.76^{*} \\
(1.25)\end{array}$ & $\begin{array}{c}4.61^{* * *} \\
(0.71)\end{array}$ & $\begin{array}{c}7.09^{* * *} \\
(0.98)\end{array}$ & $\begin{array}{l}\mathrm{F}=9.55^{* * *} \\
\mathrm{p}=0.003\end{array}$ & 128526 & 25443 \\
\hline \multicolumn{7}{|c|}{ Corollary 3: $\mathrm{V} \equiv \log$ structural estimate of iceberg costs $\tau_{j t}$} \\
\hline $\begin{array}{c}4.42^{* * *} \\
(0.83)\end{array}$ & $\begin{array}{c}8.21^{* * *} \\
(1.38)\end{array}$ & $\begin{array}{c}4.88^{* * *} \\
(0.82)\end{array}$ & $\begin{array}{l}-0.34 \\
(1.83)\end{array}$ & $\begin{array}{l}\mathrm{F}=9.71^{* * *} \\
\mathrm{p}=0.003\end{array}$ & 128526 & 25443 \\
\hline \multicolumn{7}{|c|}{ Corollary $4: \mathrm{V} \equiv \log$ structural estimate of fixed production costs $f_{j t}$} \\
\hline $\begin{array}{c}4.43^{* * *} \\
(0.76)\end{array}$ & $\begin{array}{l}2.41^{*} \\
(1.27)\end{array}$ & $\begin{array}{c}4.47^{* * *} \\
(0.75)\end{array}$ & $\begin{array}{c}6.35^{* * *} \\
(1.02) \\
\end{array}$ & $\begin{array}{l}\mathrm{F}=5.14^{* *} \\
\mathrm{p}=0.026\end{array}$ & 128526 & 25443 \\
\hline \multicolumn{7}{|c|}{ Corollary 5:V $\equiv$ Structural estimate of elasticity of substitution $\sigma_{j t}$} \\
\hline $\begin{array}{c}4.47^{* * * *} \\
(0.78)\end{array}$ & $\begin{array}{c}6.80^{* * * *} \\
(1.01)\end{array}$ & $\begin{array}{c}4.05^{* * *} \\
(0.85)\end{array}$ & $\begin{array}{l}2.45^{*} \\
(1.25)\end{array}$ & $\begin{array}{l}\mathrm{F}=6.70^{* *} \\
\mathrm{p}=0.011\end{array}$ & 128526 & 25443 \\
\hline
\end{tabular}

Notes: ${ }^{*}, * *, * * *$ statistically significant at the $10 \%$, the $5 \%$, the $1 \%$ levels, respectively. All underlying models control for time-constant unobserved firm heterogeneity and time-specific common shocks. 